\title{
Corruption and Bilateral Trade Flows: Extortion or Evasion?
}

\author{
Pushan Dutt ${ }^{*}$ \\ INSEAD
}

\author{
Daniel Traca ${ }^{\dagger}$ \\ Solvay Business School, ULB and CEPR
}

August, 2007

\begin{abstract}
This paper analyzes the impact of corruption on bilateral trade flows, highlighting the dual role of corruption in terms of extortion and evasion. While corrupt customs officials in the importing country may extort bribes from exporters they may also allow exporters to evade tariff barriers. The paper sets up a theoretical model which shows that the effect of corruption on trade flows is non-linear and must take into account the level of nominal tariffs. In particular, the model predicts that while corruption impedes trade in an environment of low tariffs, it may create trade enhancing effects, when nominal tariffs are high. We also show that the trade enhancing effect dominates at low levels of corruption, suggesting that, at high tariffs, trade flows are an inverted-U shaped function of corruption. These predictions are borne out in the data, within the framework of an augmented gravity model. The trade enhancing effect dominates for about $23 \%$ of the observations.
\end{abstract}

Keywords: Corruption, Extortion and Evasion, Gravity Model

JEL Classification Codes: F13, F15, D73

\footnotetext{
*1 Ayer Rajah Avenue, INSEAD, Singapore 138676, Email: Pushan.Dutt@,insead.edu, Ph: + 6567995498

† Université Libre de Bruxelles, Solvay Business School, ULB - CP 145/01, 1050 Brussels, Belgium, Email: daniel.traca@ulb.ac.be, Ph: +32 26506599
} 


\section{Introduction}

The last few years have seen a growing awareness of the crippling effect of corruption on economic development. Corruption has been shown to reduce economic growth (Mauro, 1995; Keefer and Knack, 1995), to distort governmental expenditures (Mauro, 1998; Tanzi and Davoodi, 1997), to retard investment (Wei, 2000), and to reduce the effectiveness of foreign aid (PSRA 2003). These results contrast sharply with earlier notions advanced by Leff (1964) and Huntington (1968) that corruption can be efficiency enhancing because it removes government-imposed rigidities that impede investment and interfere with other economic decisions favorable to growth. This view is succinctly captured in the notion that corruption "greases the wheels of trade" (Rose-Ackerman, 1997). In a country rife with onerous regulations, the opportunity to offer bribes allows firms to circumvent bad government control. Similar to deregulation, this can welfare improving (See Lui, 1985; Beck and Maher, 1986 for theoretical models). ${ }^{1}$

Bardhan (2006) argues that the impact of corruption must interact with the extent of regulations in the economy, and defines two types of corrupt behavior: on one hand, bureaucrats request bribes to do what they are supposed to do, empowered by their status as gatekeepers; on the other, they are bribed to do what they are not supposed to do, allowing firms to avoid regulations. From our perspective, it is useful to call the first type of behavior: extortion, and the second: evasion.

This paper looks at the effect of corruption of customs officials on international trade flows, stressing the dichotomy between extortion and evasion. Rose-Ackerman (1997) argues that customs officials are particularly likely to engage in corruption of both types. Extortion emerges because customs clearance procedures offer officials control over something that firms value access to and from the outside world. It affects the sharing of rents between exporters and

\footnotetext{
${ }^{1}$ However, Kaufmann and Wei (1998) argues that this view is true only in a very narrow sense; when the bad regulation and official harassment are taken as exogenous. They show that in Uganada, managers of the firms that pay more bribes on average spend more rather than less time negotiating with government officials.
} 
officials. Evasion arises as payoffs to officials are used to reduce tariffs and other regulatory barriers to trade. It augments the rents to be shared by exporters and officials.

In reality, country case studies have documented that corruption in customs facilitates both extortion and evasion. Parayno (1999) describes both forms of corrupt behavior in the Philippines, where most businesses became accustomed to giving small bribes for customs services and it was necessary to pay to "facilitate" even fully legitimate transactions, while misdeclaration, misclassification and undervaluation in formal entry declaration processing were common ways by which firms could circumvent official trade barriers, in cooperation with corrupt custom officials. Arduz (2000) describes a system in Bolivia, where most goods go through a system of "parallel customs", in which customs officers levied their own taxes rather than the official trade taxes. ${ }^{2}$ Fisman and Wei (2004) provide evidence for tariff evasion in the context of bilateral trade between Hong Kong and China. They find strong evidence for mislabeling and misclassification of imports (shifting reported imports from a higher to a lower taxed category ) but no evidence of underreporting of overall imported quantities.

We develop a theoretical model that studies the effect of both types of corrupt behavior on trade flows. Depicting the notion that a more corrupt environment reduces the expected social and legal penalties associated with bribes, we model an increase in corruption as an increase in the marginal utility of illicit income to the customs official. The net effect of corruption on trade is ambiguous, with a trade-impeding effect from extortion and a related trade-enhancing effect from evasion. Our model contributes by clarifying some important determinants of their relative size, producing two propositions. First, at any given level of corruption, the impact of a marginal increase in corruption on trade flows is affected by the level of tariffs. A higher tariff enhances the scope for the trade-enhancing tariff evasion effect of corruption. Hence, whereas for a low tariff, a rise in corruption lowers trade flows, due to extortion; for a sufficiently high

\footnotetext{
2 Similarly, Younas (2000) describes an elaborate system of bribes in Pakistan where money was levied for each and every customs transaction.
} 
tariff, a rise in corruption expands trade flows, due to evasion. Similarly, the magnitude of the effect of tariffs on trade flows is affected by the level of corruption: lowering tariffs promotes trade, but less so in more corrupt countries, where the tariffs were less effective to begin with. Second, at any given tariff level, the impact of a marginal increase in corruption on trade flows decreases, as the level of corruption increases. This means that, for meaningful tariff levels, when corruption is low, a rise in corruption increases trade flows, but when corruption is high, a rise in corruption reduces trade flows. In other words, trade flows are an inverted-U shape function of corruption. The intuition is as follows: When corruption is low, evasion is limited and has space to increase. As a result, an increase in corruption expands trade flows. On the other hand, when corruption is high, the space to expand evasion reduces, and the increase in extortion dominates. Then, a further increase in corruption reduces trade flows. In sum, a little bit of corruption helps trade, but when corruption is too high, it works as a trade barrier, at the margin.

We empirically test these propositions using an adjusted version of the gravity model. This model has enjoyed empirical success in its ability to explain a relatively large fraction of variation in the observed volume of bilateral trade. ${ }^{3}$ We extend it to account for corruption and tariffs, in line with the predictions of our model. Our theoretical model implies including terms for corruption, tariffs, their interaction, and a quadratic term on corruption interacted with tariff, which captures the inverted-U relationship outlined above. These country-specific variables raise some methodological concerns related to the multilateral trade resistance indices (Anderson and Van Wincoop, 2003), which we address through the inclusion of price-indices. Finally, we run a Heckman selection procedure on the probability of trade, following Helpman, Melitz and Rubinstein (2006), to account for the large number of zeros in the trade matrices. The selection equation includes also non-linear controls for corruption and tariffs, derived from the model.

\footnotetext{
${ }^{3}$ Feenstra (2003, chap. 5) provides an overview of this literature..
} 
Our empirical analysis lends support to both propositions, and the highly nonlinear effects of corruption and tariffs seem to be borne out by the data. First, corruption works as a deterrent to trade, but the effect is much weaker as the level of protection, as measured by nominal tariffs rise. The other side of coin is that tariffs work as a deterrent to trade, but their effect is weaker, in countries where corruption is large. Second, we also provide some evidence that the relationship between corruption and trade flows shows an inverted-U shape, for higher levels of nominal tariffs.

Overall, the results show that, for the vast majority of our observations, the trade-enhancing effect is dominated and corruption acts as an impediment to trade. However, a positive relationship between corruption and trade holds for $6.8 \%$ of our observations, in our benchmark model. ${ }^{4}$ These observations span 24 countries in our sample. In line with our prediction, we find that these countries have moderate levels of corruption and are more protectionist than average.

There is an extensive literature on the determinants of bilateral trade, looking at the effect of borders (McCallum, 1995), bilateral or multilateral trade agreements (Frankel, 1997; Rose, 2004; Subramaniam and Wei, 2005), currency unions (Frankel and Rose, 2000; Glick and Rose, 2002; Rose, 2000; Persson, 2001), conflict (Martin, Mayer and Thoenig, 2005) and infrastructure (Francois and Manchin, 2007). The effect of social institutions on trade flows was addressed, first, by Anderson and Marmouiller (2002). They show that trade expands dramatically when supported by strong institutions - specifically, by a legal system capable of enforcing commercial contracts and by transparent and impartial formulation and implementation of government economic policy. More recently, Francois and Manchin (2007) show that variations in North-South trade depend on institutional quality and access to well developed transport and communications infrastructure, much more than on variations in tariffs. In a related paper, Lamsdorff

\footnotetext{
4 This number rises to $23 \%$ in our preferred specification, where we add country fixed effects.
} 
(1999) shows that some countries have a significantly less market share in corrupt countries, and that these differences can be explained by differences in exporters' willingness to offer bribes.

To the best of our knowledge, this paper is the first to look at the role of corruption on bilateral trade flows, emphasizing the dichotomous effects of extortion and evasion. It contributes more broadly to the emerging literature on the effects of corruption, by stressing the interaction of corruption with the regulatory constraints in the economy. In doing so, we bring together the two perspectives on the effects of corruption (outlined in the first paragraph), showing not only that they are both valid, but also the conditions under which each will dominate.

\section{Theory}

\subsection{Model}

Consider a country $d$ (destination), with consumer preferences given by $U=\int_{l} x_{l}^{\frac{\varepsilon-1}{\varepsilon}}$, where $x_{l}$ is the consumption of good $l$ and $\varepsilon>1$ denotes the elasticity of substitution . Letting $Y_{d}$ denote the income/expenditure and $p_{l}$ the price of $l$ in country $d$, country $d$ 's demand for $l$ is

$$
\begin{aligned}
x_{l} & =p_{l}^{-\varepsilon} P_{d}^{\varepsilon-1} Y_{d} \\
\text { with } P_{d}^{1-\varepsilon} & =\int_{l} p_{l}^{1-\varepsilon}
\end{aligned}
$$

Assume now that $l$ is produced by a single firm from country o (origin), so that $x_{l}$ is the volume of exports of the firm to country $d$. The unit production cost of $l$, in country $o$, is given by $c$. When exporting to $d$, firm $l$ incurs in transport and border costs. Transport costs are of the iceberg type, denoted by $\lambda$. Border costs are related to customs clearance procedures. They depend on the nominal tariff in $d$ to imports from $o$, denoted by $T_{o d}(0<T<1)$ and set by trade policy. ${ }^{5}$

Customs clearance depends also on the actions of the customs official. Customs officials have the last word on whether or not the good is allowed through customs. This prompts two types

\footnotetext{
${ }^{5}$ The nominal tariff can be thought of as capturing all of country d's regulatory barriers to imports from country $o$, including import taxes and the financial and time costs of administrative procedures and inspections.
} 
of behavior by customs officials. First, customs officials may abuse their role as gatekeepers to extort bribes from the exporter, in order to allow the merchandise to transit through customs. Bribes are set through the bargaining between the exporter and the customs official. Extortion carries the risk to the official of being caught and punished by the authorities. ${ }^{6}$ We assume that a high level of corruption in the country reduces the probability of getting caught in extortion and/or the social or pecuniary penalty associated, and so increases the utility of the bribe to the customs official.

Second, officials can exert more or less zeal in making sure that the merchandise has complied with all regulatory barriers. For example, the customs official may overlook underinvoicing, allow for a wrongful classification of the merchandise into categories with lower tariffs, exonerate the merchandise from time-consuming inspections, or ignore some documentation requirements. We can thus define the effective tariff paid by the exporter as $z T$, where $0<z \leq 1$ is the zeal of the customs official. $z<1$ implies evasion of tariffs. Of course, because these actions imply weak job performance, the customs official runs the risk of being caught and punished by her supervisors. The benefit to the official is that, as a lower zeal lowers the effective tariff and increases import-rents, it raises the size of the pie over which the customs official can bargain with the exporter, for the bribe.

The impact of these types of behavior for the welfare of the customs officials can be captured in the following utility function

$$
U=b^{\psi} \exp \delta\left(1-z^{-1}-\ln z\right) \quad 0<\psi<1
$$

where $b$ is the amount of the bribe and $\psi$ denotes the level of corruption $(0<\psi<1) .{ }^{7}$ Note that $\psi=0$, depicting a corruption-free environment, implies that there is no utility to the

\footnotetext{
${ }^{6}$ For simplicity, we assume that the bribe is the only source of revenue for the customs officer, who will not obtain any other benefit from allowing for a lower effective rate.

${ }^{7}$ This utility function ignores other income or wealth of the official, and thus cannot capture some important determinants of corruption, such as low salaries. In this paper, we focus on the role of trade variables for the returns to corruption. The analysis is greatly simplified by this utility function.
} 
customs official from the bribe. Moreover, (2) posits that the marginal utility of an increase in the bribe is positive $\left(U_{b}^{\prime}>0\right)$ and increases with the level of corruption, as the latter lowers the expected penalty to the customs official of being caught in extortion. On the other hand, (2) implies that an increase in zeal raises the official's utility $\left(U_{z}^{\prime}>0\right)$. Note that, here, we are implicitly assuming that the decline in expected sanctions outweighs the potential costs of a higher effort. Parameter $\delta$ captures the supervision of the customs' official (including her own sense of duty) in enforcing the legal border procedures, - a higher $\delta$ implies a higher cost of lowering zeal. ${ }^{8}$

Exporting good $l$ to country $d$ from country $o$ happens in three stages. In stage one, the exporter decides the quantity to export and the shipment makes its way to the customs of $d$, incurring in the transport costs. In stage two, when reaching country $d$, the merchandise must go through customs procedures. At this stage, the customs official must decide the zeal with which she will implement the nominal tariff. Finally in stage three, at the final step of the customs clearance procedure, the customs official may engage in extortion and require a bribe to allow the merchandise through.

In this context, the total profit of firm $l$ in country $d$ 's is given by

$$
\begin{aligned}
\Pi & =\pi-\lambda c x_{l} \\
\pi & =p_{l} x_{l}(1-z T)-b
\end{aligned}
$$

where $p_{l} x_{l}(1-z T)$ are the revenues obtained from the sale of the merchandise in $d$ net of the effective tariff. By lowering zeal, the custom's official raises the revenues. Then, in stage three, the bribe works as rent-sharing device between the exporter and the customs official, with $\pi$ denoting the rents captured by the exporter. ${ }^{9}$ Ultimately, by affecting the continuation payoff

\footnotetext{
${ }^{8}$ It could be argued that, in a more corrupt environment, supervision declines as the sense of guilt of officers in avoiding regulatory procedures declines. We will ignore this mechanism, and focus on the impact of corruption on the size of the bribe.

${ }^{9}$ Through this sequencing we capture the notion that bribes are likley to be paid only when the merchandise
} 
of the firm $(\pi)$, the bribe $(b)$ and the zeal of the customs official $(z)$ affect the firm's earlier decisions on the exports to ship to country $d$, in stage one.

\subsection{Equilibrium}

In this section we characterize the equilibrium of our model, including the bribe, the customs official decision on zeal, and the firm's decision on exports. We use backward induction to solve the model, beginning in stage three with the firm and the official bargaining for the bribe.

\subsubsection{Bribes/ Extortion (stage 3)}

We model the negotiation between the official and the exporter as the outcome of a Nashbargaining game. ${ }^{10}$ Since, at this stage, the merchandise is sitting as customs (and production and transport costs are sunk), we take value of the merchandise given, and denote it by $\overline{p x}$. For simplicity, we assume that the reservation payoff for both parties is zero. ${ }^{11}$ The solution to the Nash-bargaining problem that determines the bribe thus emerges from

$$
\begin{aligned}
& \max _{b} \ln U+\ln \pi \\
& \max _{b}\left[\psi \ln b+\delta\left(1-\bar{z}^{-1}-\ln \bar{z}\right)\right]+\ln \left(\overline{p_{l} x_{l}}(1-\bar{z} T)-b\right)
\end{aligned}
$$

We can solve for the bribe paid, and obtain how revenue net of effective tariff is shared between the exporter and the customs official

$$
\begin{aligned}
b & =\frac{\psi}{1+\psi} \overline{p_{l} x_{l}}(1-\bar{z} T) \\
\pi & =(1+\psi)^{-1} \overline{p_{l} x_{l}}(1-\bar{z} T)
\end{aligned}
$$

clears customs and after the official has already facilitated most of the clearence procedure. The firm cannot commit to an evasion contract, because these transactions cannot be protected by enforceable contracts.

${ }^{10}$ Rose-Ackerman (1997) argues that "bribery (...) seldom occurs under competitive market conditions. Instead, a bargaining framework is often appropriate."

${ }^{11}$ The implicit assumption is that the official has absolute gatekeeping power and that production and transport costs are sunk for the exporter. As a result, if refused entry, due to the discretion of the customs officer, the merchandise cannot be diverted elsewhere or reshipped back to country $o$. For the customs official, the zeal in the customs clearance process has already been deployed in stage three. Her reservation utility is zero (no bribe), given (2). 
In this context, an increase in corruption $\psi$ raises the share of the customs official, since the rise in impunity increases the marginal utility of asking for a higher bribe.

\subsubsection{Zeal/ Evasion (stage 2)}

In stage 2 , the customs official decides on how much zeal to deploy. This is a simple optimization by the customs official, who takes into account the impact of her zeal on the bribe that she will be able to extract. Given (4), the official's problem can be written:

$$
\max _{z}\left[\psi \ln \left(\frac{\psi}{1+\psi} \overline{p_{l} x_{l}}(1-z T)\right)+\delta\left(1-z^{-1}-\ln z\right)\right]
$$

Taking the first order condition, we obtain

$$
\delta\left(z^{-2}-z^{-1}\right) \geq \psi \frac{T}{1-z T}(=0 \text { if } z<1)
$$

Equation (5) is plotted in Fig.1, along with the solution $(\tilde{z})$. The LHS denotes the marginal gain to customs official from raising the zeal and is decreasing in $z$. The RHS captures the marginal cost of increasing zeal, in terms of lowering the continuation rents, and is increasing in $z$. Note that in the benchmark no-corruption case where $\psi=0, z$ is set to 1 and there is no evasion.

Figure 1 shows how the equilibrium zeal responds to changes in corruption, supervision and nominal tariffs. A rise in corruption $(\psi)$ leads to a decline in the equilibrium level of zeal, as it raises the ability of the customs official to benefit from the extra rents created by evasion, through their impact on the bribe. On the other hand, an increase in supervision $(\delta)$ leads to an increase in zeal, since it raises the marginal cost of allowing for evasion. Finally, by raising the marginal rents from evasion, an increase in $T$ lowers $z$, although the effective tariff $(z T)$ increases. $^{12}$

\footnotetext{
12 To see that the effective tariff raises with $T$, rewrite $(5)$ as: $z T=\left(1+(\psi / \delta)\left(z^{-1}-1\right)^{-1}\right)^{-1}$, which implies that $z T$ is decreasing in $z$, which, as seen above, is decreasing in $T$. Supportive evidence is found in Pritchet and Sethi (1994) who show that, as tariff rates rise, effective tariffs fall as a share of nominal tariffs and the variance of rates actually paid increases.
} 


\subsubsection{Exports (stage 1)}

In stage one, the exporter decides on the volume of exports to ship to $d$, given the likely actions of the country's customs officials. The decision is to maximize profits, given by $\Pi$, which can be written

$$
\max _{x_{l}} \Pi=(1+\psi)^{-1}(1-\tilde{z} T) p_{l} x_{l}-c x_{l} \lambda
$$

where $\tilde{z}$ is the optimal effort deployed by the customs official from 5 . Given the demand function outlined at the beginning, the profit maximization yields the traditional expression for the mark-up in terms of the elasticity of substitution $(\varepsilon)$

$$
\begin{gathered}
p_{l}=p=\frac{\varepsilon}{\varepsilon-1} \lambda c \frac{(1+\Delta)}{(1-T)} \\
\text { with } \quad(1+\Delta) \equiv(1-T)(1-\tilde{z} T)^{-1}(1+\psi)
\end{gathered}
$$

where we call $\Delta$ the corruption tax. It captures the rise in the price at $d$ due to the actions of customs officials facilitated by the presence of corruption. In the benchmark, no-corruption case $(\psi=0 ; z=1)$, the corruption tax is zero. Moreover, from (1) and (6), we can obtain the exports of $l$ in country $d$

$$
x_{l}=x=[(1+\Delta) /(1-T)]^{-\varepsilon}(\lambda c)^{-\varepsilon}\left(\frac{\varepsilon}{\varepsilon-1}\right)^{-\varepsilon} P_{d}^{\varepsilon-1} Y_{d}
$$

where the role of corruption is captured through its effect on the corruption tax. An increase in the corruption tax lowers the volume of exports of firm $l$ to country $d$. Moreover, from (3) and (6), we obtain

$$
\Pi=[(1+\Delta) /(1-T)]^{-\varepsilon}(\lambda c)^{1-\varepsilon} P_{d}^{\varepsilon-1} Y_{d}(\varepsilon-1)^{\varepsilon-1} \varepsilon^{-\varepsilon}
$$

which, like before shows that corruption's effect on profits to the exporter is captured through its effect on the corruption tax. An increase in the corruption tax lowers the export profits to firm $l$. 


\subsection{Corruption Tax}

This section looks at how the corruption tax $\Delta$ is affected by increases in the level of corruption, $\psi$. To see this, we can use (5) and (7) to rewrite the corruption tax as:

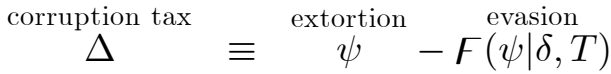

$$
\begin{aligned}
& \text { where } \digamma(\psi \mid \delta, T) \equiv \delta \frac{1+\psi}{\psi}(1 / z(\psi, \delta, T)-1)^{2} \geq 0
\end{aligned}
$$

Eq. (10) separates the impact of corruption on the two actions of the customs official: extortion and evasion. When $\psi=0$ (i.e. in a corruption-free environment), we have $\tilde{z}=1$, and both components of the corruption tax are zero. For $\psi>0$, the first term, extortion $(\psi)$, is positive, as an increase in corruption raises the corruption tax by raising the bribe captured by the official, due to the increase in impunity. On the other hand, the second term, evasion $(-\digamma)$, is negative, i.e. corruption lowers the corruption tax, as the customs official lowers her zeal, reducing the effective tariff. As a result, the net impact of corruption on the corruption tax can be positive or negative, depending on how the impact on extortion (i.e. the bribe) compares with the effect on evasion.

In Fig.2a, we plot $\digamma$ in terms of $\psi$, for different values of $T$, with $\digamma_{i} \equiv \digamma\left(\psi \mid T_{i}\right)$, where $T_{D}>T_{C}>T_{B}>T_{A}=0 .{ }^{13} \quad$ Eq. (10) implies that differences to the 45-degree diagonal give the value of the corruption tax, which is shown in Fig. $2 \mathrm{~b}$.

Beginning with the case where $T=0$, we have that $\digamma_{A}=0, \forall \psi$, capturing the notion that there is no scope for evasion. In this case, the corruption tax increases linearly with corruption $(\Delta=\psi)$, due to the effect on extortion. The case where $T>0$ is captured by $\digamma_{B}, \digamma_{C}$ and $\digamma_{D}$. A first point to note is that $\digamma$ is increasing and concave in $\psi\left(\partial \digamma / \partial \psi>0, \partial^{2} \digamma / \partial \psi^{2}<0\right)$, and increases with $T(\partial \digamma / \partial T>0)$. This means that corruption raises evasion, but does so at

\footnotetext{
${ }^{13} z(\psi, \delta, T)$ can be obtained as the root to the quadratic equation obtained from the manipulation of (5); namely $1-z(1+T)+\left(1-\frac{\psi}{\delta}\right) z^{2} T=0$, which entails $z(\psi, \delta, T)=\frac{1+T}{2 T} \frac{1-\left[1-\left(1-\frac{\psi}{\delta}\right)\left(1-\left(\frac{1-T}{1+T}\right)^{2}\right)\right]^{1 / 2}}{1-\frac{\psi}{\delta}}$
} 
decreasing rates. The reason is that the potential for further lowering zeal declines, as corruption and evasion increase. For high values of $T, \digamma$ rises above the 45-degree line, particularly at low values of corruption, where the marginal impact on regulatory evasion is high.

The implication is that the corruption tax is a convex function of corruption, when $T>$ $0\left(\partial^{2} \Delta / \partial \psi^{2}>0\right)$. More important, the corruption tax can be a non-monotonic, U-shaped function of corruption, if $T$ is large enough for the effect on evasion to dominate. The interaction of $\psi$ with $T$ generates some important nonlinearities.

If $T>0$ is not too large (e.g. $\left.T_{B}\right)$, the corruption tax is increasing $(\partial \Delta / \partial \psi>0)$. In this case, there is scope for evasion, which helps reduce the corruption tax, but not enough to outweigh the effect on bribes. Given the discussion in the previous sections, in the case an increase in corruption has a negative impact on trade flows to $d$. At higher values of $T$ (e.g. $T_{C}$ ), the potential for evasion strengthens. And since the scope for evasion is stronger at lower levels of corruption (where the scope to lower zeal is higher), the corruption tax can turn negative at low levels of corruption, only to became positive later, when the scope for evasion shrinks. Thus the corruption tax becomes a U-shaped function of corruption. Note that a negative corruption tax, for low levels of corruption, implies that an increase in corruption has a positive impact on trade flows to $d$. Finally for $T$ very large (e.g. $\left.T_{D}\right)$, the potential for evasion is such that the corruption tax is always negative. In this case, corruption is trade promoting, although it remains possible that there are some nonlinearities as the marginal effect may become positive at high levels of corruption.

The predictions of the model for the effect of corruption on the corruption tax be summarized in the following two testable propositions, which we enunciate without proof, given the discussion above:

Proposition 1 Interaction with Tariffs: The effect of corruption on the corruption tax, is weaker, and can become negative, as the nominal tariff increases.

Proposition $2 U$-shaped Corruption Tax : For any given high level of the nominal tariff, 
an increase in corruption is more likely to (a) increase the corruption tax, if the initial level of corruption is high; and (b) to reduce the corruption tax, if the initial level of corruption is low.

\section{$3 \quad$ An augmented gravity model}

To examine the relationship between trade flows and corruption we extend the gravity model to include the corruption tax. This model has enjoyed empirical success in its ability to explain a relatively large fraction of variation in the observed volume of bilateral trade. Empirically, the model has been used to analyze border effects (McCallum, 1995), the effects of regional trade blocs (Frankel, 1997) the effect of GATT/WTO on trade flows (Rose, 2004; Subramaniam and Wei, 2005), the effect of currency unions on trade (Frankel and Rose, 2000; Glick and Rose, 2002; Rose, 2000; Persson, 2001) and the size of home-market effects (Davis and Weinstein 2003). Microfoundations for the gravity model has been provided by a variety of papers, including Anderson (1979), Bergstrand (1989), Deardorff (1998), Anderson and van Wincoop (2003). Both monopolistic competition and Heckscher-Ohlin market structures have been employed to derive the gravity equation.

Here, we follow Anderson and van Wincoop (2003) to expand the gravity equation to account for the corruption tax. We introduce the subscript od to denote all variables that are specific to that country-pair $o$ and $d$, such as $T_{o d}$ which measures the legal tariff rate in $d$ to imports from $o, \lambda_{o d}$ the transport costs between $o$ and $d \cdot{ }^{14}$ Let the unit cost of $l$ be given by $c=w_{o}$, where $w_{o}$ is the wage in country $o$. Suppose also that $N_{o}$ measures the number of goods produced in country $o$. Then, from (8) and (6), the total value of total exports of $o$ to $d$ are given by ${ }^{15}$

$$
X_{o d}=\int_{l} p_{d} x_{d}=N_{o} w_{o}^{1-\varepsilon}\left(\frac{\varepsilon}{1-\varepsilon}\right)^{1-\varepsilon}\left[\left(1+\Delta_{o d}\right) /\left(1-T_{o d}\right)\right]^{1-\varepsilon} \lambda_{o d}^{1-\varepsilon} P_{d}^{\varepsilon-1} Y_{d}
$$

Following the gravity literature, we can define the income in country $o$ equal to what it sells to

\footnotetext{
14 As before, the subscripts $o$ and $d$ denote variables specific to the exporting country $(o)$ and the importing country $(d)$, respectively.

${ }^{15}$ For simplicity, we assume that imports are valued at a price that includes the border cost.
} 
every country including itself so that

$$
Y_{o}=N_{o} \sum_{k} p_{k} x_{k}
$$

where we must be careful that the output of goods produced within the country is not subject to trade costs. Given (8), and using (1) and (6) to solve for $P_{d}$, we can obtain

$$
Y_{o}=N_{o} w_{o}^{1-\varepsilon}\left(\frac{\varepsilon}{1-\varepsilon}\right)^{1-\varepsilon} Y_{w} \Upsilon_{o}^{1-\varepsilon}
$$

with,

$$
\begin{aligned}
& \Upsilon_{o}^{1-\varepsilon}=P_{o}^{\varepsilon-1} \theta_{o}+\sum_{d \neq o}\left[\left(1+\Delta_{o d}\right) /\left(1-T_{o d}\right)\right]^{-\varepsilon} \lambda_{o d}^{1-\varepsilon} P_{d}^{\varepsilon-1} \theta_{d} \\
& P_{d}^{1-\varepsilon}=\Upsilon_{d}^{\varepsilon-1} \theta_{d}+\sum_{o \neq d}\left[\left(1+\Delta_{o d}\right) /\left(1-T_{o d}\right)\right]^{1-\varepsilon} \lambda_{o d}^{1-\varepsilon} \Upsilon_{o}^{\varepsilon-1} \theta_{o}
\end{aligned}
$$

where $\theta_{j}=Y_{j} / Y_{w}$ and $Y_{w}=\sum_{j} Y_{j}$ is world income. $\Upsilon_{o}$ and $P_{d}$ are price-levels for the two countries. $P_{d}$ is the price index for consumers in $d$, whereas $\Upsilon_{o}$ is the is the price index for firms' sales. The terms $P_{o}^{\varepsilon-1} \theta_{o}$ and $\Upsilon_{d}^{\varepsilon-1} \theta_{d}$ capture the goods produced in the respective country, which are not subject to transport or border costs. Finally, we can use (14) to substitute for $N_{o} w_{o}^{1-\varepsilon}\left(\frac{\varepsilon}{1-\varepsilon}\right)^{1-\varepsilon}$ in $(12)$ to obtain

$$
X_{o d}=\left(\frac{1+\Delta_{o d}}{1-T_{o d}}\right)^{1-\varepsilon} \lambda_{o d}^{1-\varepsilon} \frac{Y_{d} Y_{o}}{Y_{w} P_{d}^{1-\varepsilon} \Upsilon_{o}^{1-\varepsilon}}
$$

This expression augments the traditional gravity equation to include border costs, captured by the term $\left(1+\Delta_{o d}\right) /\left(1-T_{o d}\right)$. Note that, since $\varepsilon>1$, the sign of the effects of corruption on trade flows is the opposite of its effect on the corruption tax. As a result, proposition 2 implies a inverted-U shaped relationship between bilateral trade flows and corruption.

The traditional components include transport costs, the size of market, for exporters and importers, captured by $Y_{o}$ and $Y_{d}$, and the price-indices: $P_{d}$ and $\Upsilon_{o}$. These price indices are addressed as the multilateral trade resistance by Anderson and van Wincoop (2003) and as "relative-prices-matter-term" by Baldwin (2006). The multilateral trade resistance terms 
reflect both the openness of the importing nation to all goods and the openness of the world to the exporter's goods (not simply the openness of a pair of exporter and importer). Trade between any pair of countries depends on their bilateral trade costs (including here transport and border costs) relative to average trade costs with all trade partners (measured by the multilateral trade resistance terms).

As discussed at length in the literature (see Baldwin, 2006), the multilateral resistance term raise an important caveat for the role of bilateral trade costs on trade flows. If trade costs are reduced among a set of countries that already trade a lot with each other, multilateral trade resistance will drop a lot and relative trade resistance will fall little. The drop in multilateral resistance of member countries reduces the impact of the reduction of bilateral trade costs on trade between any pair of countries. Hence, the omission of a control these multilateral trade resistance terms biases estimates of the trade costs toward zero.

Accounting for these terms is very important in the context of this paper, because the components of border costs we estimate (i.e. tariffs and corruption) are likely to affect the majority of imports into a country. Hence they are an important determinant of the multilateral trade resistance indices. To see the implications of this, assume that the border cost is importcountry specific, affecting all firms exporting to country $d$, i.e. $\left(1+\Delta_{d}\right) /\left(1-T_{d}\right)$. Then, if we re-write (16) by replacing $P_{d}$ with the expression in (15), we obtain

$$
X_{o d}=\frac{\lambda_{o d}^{1-\varepsilon} Y_{d} Y_{o} / Y_{w} \Upsilon_{o}^{1-\varepsilon}}{\sum_{o \neq d} \lambda_{o d}^{1-\varepsilon} \Upsilon_{o}^{\varepsilon-1} \theta_{o}+\left[\left(1+\Delta_{d}\right) /\left(1-T_{d}\right)\right]^{\varepsilon-1} \Upsilon_{d}^{\varepsilon-1} \theta_{d}}
$$

This expression shows that, if we do not control for multilateral trade resistance, the border cost affects bilateral trade flows from $o$ to $d$, only to the extent that it affects the choice of $d^{\prime}$ s consumers between imported goods (regardless of their origin) and locally produced goods (which do not pay border costs). Note that, if the local economy is very small $\left(\theta_{d} \simeq 0\right.$ ), the border cost has no effect on the bilateral trade-flows. The important point is that estimates of the border cost that do not control for multilateral trade resistance would clearly underestimate 
its magnitude of the border cost. In the estimation procedure that follows, we will always include controls for multilateral trade resistance.

\section{Estimation}

\subsection{Specification}

In this section, we use (16) to produce an estimable equation. First, we obtain a polynomial approximation for the corruption tax, given the expression in (10). Using (11), we can take a second order approximation to $\digamma$ to obtain

$$
\digamma_{o d} \simeq\left(d_{1} \psi_{d}-d_{2} \psi_{d}^{2}\right) T_{o d}
$$

where $d_{1}>d_{2} / 2>0$ ensures that $\digamma$ is increasing and concave for $\psi \leq 1{ }^{16}$ It implies also that $\digamma$ is zero when $\psi=0$ or $T=0 .{ }^{17}$ Given (10), we can obtain

$$
\Delta_{o d} \simeq \psi_{d}-d_{1} \psi_{d} T_{o d}+d_{2} \psi_{d}^{2} T_{o d}
$$

Now, to obtain the country-pair specific nominal tariff, we take into account the possibility that the trading partners are involved in a customs-union or a free-trade-area. Specifically, letting $\gamma_{o d}$ denote a trade-agreement dummy, that takes the value 1 if the two countries are members of a free trade area (FTA) or a customs unions (CU) or have a bilateral trade-agreement, we can express $T_{o d}$ as

$$
T_{o d}=\left(1-\gamma_{o d}\right) T_{d}
$$

where $T_{d}$ is the importing-country specific nominal tariff.

Finally, taking a log-linearization of (16), this produces the following estimable equation

$$
\begin{aligned}
& \ln X_{o d t}=a_{1} \psi_{d t}+a_{2} \psi_{d t} T_{o d t}+a_{3} \psi^{2} T_{o d t}+a_{4} T_{o d t}+\mathbf{\Theta} \mathbf{Z}_{o d t} \\
& +b_{1} \ln Y_{d t}+b_{2} \ln Y_{o t}+b_{3} D_{t}+c_{1} \ln \Upsilon_{o}+c_{2} \ln P_{d}+C+\epsilon_{o d t}
\end{aligned}
$$

\footnotetext{
${ }^{16}$ In all our estimates this condition can be seen to hold.

17 These features of $\digamma$ were discussed in section 2.3.
} 
where we have added time-subscripts to the variables. This equation can be estimated using data on the trade flows between country-pairs.

The coefficients denoted by $a$ are our main coefficients of interest. From (16) and (18), our model's predictions imply $a_{1}=-\varepsilon<0, a_{2}=\varepsilon d_{1}>0, a_{3}=-\varepsilon d_{2}<0, a_{4}=-\varepsilon<0$. Estimation would require measures of corruption and tariff rates. The term $\mathbf{\Theta} \mathbf{Z}_{o d t} \equiv(1-\varepsilon) \ln \lambda_{\text {odt }}$ captures a host of traditional gravity variables that are related to transport costs, such as geographical, cultural and linguistic distance. The $b$ coefficients look at the impact of country incomes on trade, and can be estimated using data on GDP. Following the traditional gravity literature, our expectations are that $b_{1}=b_{2}=1$. Also following the gravity literature, $b_{3}$, which depicts the effect of global GDP $\left(Y_{w}\right)$, can be proxied by a set of time-dummies $\left(D_{t}\right)$.

The $c$ coefficients capture the impact of multilateral trade resistance terms, and our model suggest $c_{1}=c_{2}=(1-\varepsilon)<0$. Accounting for the multilateral trade resistance terms has proved challenging and various papers employ different fixes for the problem. A series of papers use country-specific fixed effects for source and destination country to control for the multilateral trade resistance terms (See Harrigan, 1996; Hummels, 1999; Rose and van Wincoop, 2001). Using fixed effects in this manner also dramatically reduces the scope for omitted variables and mis-measurement that may plague our estimates, as the intercepts take out all variation that is not specific to bilateral pairs. Baldwin (2006) argues that time-invariant country-specific fixed effects may not suffice, since omitted terms reflect factors that vary every year, so the country dummies need to be time varying. ${ }^{18}$ This is not feasible in the context of our paper since we will not be able to identify the coefficient of interest - corruption in the importing country - which is importing country specific, and not country-pair specific (see also Francois

\footnotetext{
${ }^{18}$ Feenstra (2002) argues that the fixed effects method provides consistent estimates of the average border effect across countries and recommends this as the preferred empirical method given the simplicity in its implementation. However, Frankel (2006) argues, that the trade diversionary role of the multilateral trade resistance indices may be overemphasized in the literature, and that adding a plethora of dummies (for time- and country-specific fixed-effects) entails eliminating a lot of variation in the data, with a consequent, unwarranted loss in statistical significance.
} 
and Manchin , 2007). Therefore, we follow Baier and Bergstrand (2001), and use measures of the price-level (e.g. GDP deflators, unit values) as proxies for the multilateral trade resistance terms. In addition, to capture other country-specific, time-invariant factors, we include also fixed-effects in the regressions. We include fixed-effects of two types: at the country level, for exporters and importers, and at the level of unidirectional country-pairs (example, one dummy for exports from US-Canada and a separate dummy for exports from Canada-US) ${ }^{19}$

\subsection{Data}

\subsubsection{Bilateral Trade Flows}

We measure bilateral trade as the value of imports (cost including freight) from IMF's Direction of Trade Statistics. We have data for 90 exporters and 84 importers over the period 1982-2000. Out of all possible trade flows between pairs of countries, $24.5 \%$ exhibit zero trade. While more comprehensive data is available for bilateral imports, as a robustness check, we also present results using bilateral exports. As suggested by the gravity model all data are in current US dollars. $^{20}$

\subsubsection{Corruption}

We use the International Country Risk Guide (ICRG) survey based index of corruption. The measure, used previously and described in detail in Knack and Keefer (1993), codes corruption in different countries on a zero to six scale, with low scores indicate high levels of corruption. To avoid awkwardness in the interpretation of the coefficients, the ICRG was recoded as six minus the original corruption index, so that now higher numbers indicate higher corruption.

The ICRG index measures the likelihood that government officials demand special payments and that illegal payments are generally expected throughout lower levels of government in the form of bribes connected with import and export licenses, exchange controls, tax assessment,

\footnotetext{
${ }^{19}$ It seems reasonable that exports of Canada to the US face a different demand function than do US exports into Canada, and that US export prices are determined by different factors than are Canadian export prices.

${ }^{20}$ Table 1 presents the summary statistics for all variables.
} 
policy protection, or loans. While we are concerned with corruption in customs in this paper, there is no measure of corruption available across countries and over time that exactly captures corruption in customs. ${ }^{21}$ The ICRG measure has the most extensive coverage, across countries and over time (1982-2004). Since a single survey methodology is used, cross-country and overtime comparisons using this measure are likely to be valid. However, as with all research that employs corruption data, we must recognize these are subjective assessments of corruption and subject to measurement error.

We include additional variables to control for the institutional characteristics of a country which may influence both trade flows and corruption levels. Exclusion of these may lead to a potential omitted variable bias. In particular, we use the Polity measure of democracy (Polity IV project), ${ }^{22}$ and an indicator of political constraints constructed by Henisz (2000). The last variable is created by coding the number of veto points among various branches of government (executive, legislature, judiciary) and captures the extent to which the executive faces political constraints. Finally, as an additional control, we include corruption in the exporting country.

\subsubsection{Trade Policies}

The country-specific legal tariff rate is obtained from two measures of trade policy: (1) total import duties collected as a percentage of total imports from the World Development Indicators ${ }^{23}$ $\left(T^{M D}\right)$, and (2) the unweighted average external tariff data recently made available by the World Bank $\left(T^{W B}\right)$. While none of these measures are perfect, Rodrik and Rodriguez (2000) argue that these are the most direct measures of trade restrictions, that there is little evidence

\footnotetext{
${ }^{21}$ One way to examine whether the ICRG is a good proxy for corruption in customes is to examine its correlation with the German exporter corruption index (available for a single year for 43 countries from Neumann, 1994) which measures the total proportion of deals involving kickbacks, according to German exporters. Neumann's measure has the advantage that it captures corruption in customs and that it can be given a cardinal interpretation. This measure has a correlation of 0.9 with the ICRG measure.

${ }^{22}$ Note that we used the POLITY2 measure, which transforms the Polity "standardized authority codes" (i.e., $-66,-77$, and -88) to scaled POLITY scores so the POLITY scores may be used consistently in time-series analyses without losing crucial information by treating the "standardized authority scores" as missing values.

${ }^{23}$ Note the import duty measure is a weighted average of import duties on each good where the weights are the share of imports of that good in total imports.
} 
for the existence of serious biases in these indicators, and that they do a relatively decent job in ranking countries according to the restrictiveness of their trade regimes. Finally, we present additional robustness results using the average tariff rate in Barro and Lee (1993), available for a single year in the 1980s $\left(T^{B L}\right)$. This variable includes tariffs, duties and customs fees, and is calculated by weighing each import category by the fraction of world trade in that category.

\subsubsection{Transport costs, GDP and Price Indices}

We use traditional gravity variables such as geographic distance, contiguity, colonial links, and linguistic similarities, to capture factors that facilitate or impede trade. Data on these variables are obtained from the CEPII bilateral distance database (www.cepii.fr). We also include a dummy for membership in GATT/WTO from Rose (2004). ${ }^{24}$ Data on nominal GDP and GDP price deflators are from the World Development Indicators, while export and import unit values (used in a subset of regressions) are from International Finance Statistics (IMF).

\section{$5 \quad$ Econometric Results}

This section looks at the empirical support for our theoretical predictions. We show results with multiple measures of bilateral trade flows and tariff protection, that control for selection bias, and examine the robustness of our results to various sub-samples and to an alternate empirical methodology.

\subsection{Import-duties}

Table 2 presents OLS estimates of (19), using import-duties $\left(T^{M D}\right)$ as a measure of the nominal tariff rate. All models include year dummies and standard errors are adjusted for clustering on country-pairs. ${ }^{25}$ Column 1 simply analyzes the direct effects of corruption and tariffs while

\footnotetext{
${ }^{24}$ One variable is coded as 1 if both trading partners are members of GATT/WTO and a second variable is coded as one if at least one of the trading partners is in GATT/WTO.

${ }^{25}$ The time dummies should pick up global trends in inflation rates, as well as an across-the-board increase in trade flows across all countries.
} 
columns 2-5 focus on the interaction of corruption and import-duties. All columns, except column three, use GDP deflators to proxy the price levels. As discussed above, using GDP deflators to proxy for the multilateral trade resistance can be criticized, because the latter should include only the price of traded goods. Following Gould (1994), column four replaces the GDP deflators with the export and import unit values from the IFS database. Given the lack of country coverage of this data, our sample size falls dramatically. Hence we present results with this variable more as a robustness check. Columns 4 and 5 estimate the model with country-specific and country-pair dummies, respectively. In the latter, time-invariant country pair specific variables like distance, colonial links cannot be estimated.

All models are jointly significant at the $1 \%$ level and account for at least $70 \%$ of the variation in trade flows. Overall, the traditional gravity variable estimates are in line with the literature: positive for GDP, contiguity, colonial links, linguistic similarity and negative for distance. The coefficients on GDP are insignificantly different from unity, as established by other researchers. In line with Rose (2004), being a member of the GATT/WTO does not increase trade, once country-dummies are included. Our signs on GDP deflators are negative, as expected, and are significant once we include fixed-effects. We also find the corruption in the exporting country has a negative sign, although it becomes statistically insignificant when country-dummies are included (columns 5 and 6 ). We find that countries with better political institutions in terms of political constraints on the executive tend to trade more with one another. However, contrary to previous work, we find that democracies do not make natural trading partners - we obtain negative coefficient on the Polity score in both the exporting and the importing country. ${ }^{26}$

Looking at our variables of interest, in column one, we obtain negative and significant coefficients on both corruption and import duties. Column 2 adds the two interaction terms -

\footnotetext{
${ }^{26}$ Our results can be interpreted in the following way: countries with greater constraints on the executive tend to have more stable policies (trade and otherwise). This facilitates trade. Simply being a democracy matters much less.
} 
tariff $^{*}$ corruption and tariff $^{*}$ corruption $^{2}$ - to evaluate whether the effect of corruption on trade flows is conditional on the level of protectionism and is inverted-U shaped. As predicted, we obtain a positive sign on tariff $^{*}$ corruption and a negative sign on tariff $^{*} \operatorname{corruption}^{2}$, while the signs on corruption and tariff are negative and significant. These results remain substantively unaffected, when, in column four, we use the export- and import-unit values to proxy the multilateral trade resistance terms.

Overall, the highly nonlinear effects of corruption and tariffs seem to be borne out by the data. For the vast majority of our observations, corruption acts as a tax on trade. However, a positive relationship between corruption and trade holds for $6.8 \%$ of our observations. This means that the positive relationship is observed for 24 of the 84 countries in our sample, for at least one of the years for which we have data. Examining the summary statistics for this subset of countries, we find that they have moderate levels of corruption (the corruption measure ranges from 1 to 3.3) and that they are in general, more protectionist. We find that only $10 \%$ of our overall sample exhibits an import duty of greater than $20 \%$, whereas for the sub-sample with a positive relationship corruption and trade flows nearly $50 \%$ of observations show an import duty of greater than $20 \%$. These results are in line with our propositions that corruption has the potential to increase trade for countries that are a) highly protectionist and b) not extremely corrupt. Our results also imply that reducing tariffs may not increase trade flows in countries with high levels of corruption, where formal trade barriers are less effective due to evasion.

Column 4 adds the export and import country-specific, time-invariant dummies, which control for omitted country characteristics. Once again we find support for our proposition that the effect of corruption on trade is contingent upon the prevalent levels of trade protection. Here, the coefficient on tariff* corruption ${ }^{2}$ is no longer significant even though they have the right sign. Ignoring this insignificant interaction term, we find that $23 \%$ of our observations exhibit a positive relation between corruption and trade flows. For 45 countries in our sample, 
an increase in corruption in that country can actually induce an increase in bilateral trade. ${ }^{27}$

As a final check, column 5 replaces the importer and exporter dummies with country pair dummies (distinct dummies are used for exports from $i$ to $j$ and for exports from $j$ to $i$.) Once again, we obtain negative coefficients on tariffs, corruption in the importing country and a positive coefficient on the interaction term. In fact, these coefficients are similar in magnitude to the estimates shown in column 4 where we use importer and exporter dummies. As in column 4, the coefficient on tariff* corruption $^{2}$ is not significant.

\subsection{Unweighted tariff data}

Table 3 presents a similar set of regressions using the unweighted average tariff $\left(T^{W B}\right)$ measure. Column 1 shows our results without the interaction terms, while column 2-5 include both interaction terms. Column 2 uses the GDP deflators, column 3 uses the import and export unit values as proxies for the multilateral trade resistance terms. Column 4 includes export and import country specific dummies, and column 5 uses country-pair dummies.

Similar to table 1, columns 2 and 3 show that both interaction terms are strongly significant and of the predicted sign so that corruption's effect on trade flows is contingent on the nominal tariff measure $\left(T^{W B}\right)$. Columns 4 and 5 show that adding either set of country dummies makes both interaction terms insignificant. However, if we drop the tariff* $^{*}$ corruption $^{2}$ term, the interaction of tariff* corruption becomes significant. ${ }^{28}$ In the benchmark model of column 2 , the estimates predict a positive relation between corruption and trade flows for $25 \%$ of the observations. Again, we find that in the countries who fall in this subset, the corruption measure takes values less than 4 (they are moderately corrupt) and that $80 \%$ have an unweighted tariff in excess of $20 \%$. In contrast, only $20 \%$ of all observations in the sample have an unweighted tariff

\footnotetext{
27 This does not imply that the relationship between corruption and trade is always positive for each of the countries since both corruption and tariffs change over time. For example, for Costa Rica as an importer, this is true for only two years whereas for Pakistan this is true for sixteen years.

${ }^{28}$ Our results in the next section show that once we control for selection effects, the interaction term becomes significant for the $T^{W B}$ measure as well.
} 
in excess of $20 \%$. This again shows that countries that exhibit a positive relationship between corruption and trade protection are those that are moderately corrupt and highly protectionist.

\subsection{Selection-bias}

A recent paper by Helpman, Melitz and Rubinstein (2006) criticizes the traditional gravity model on the grounds that it includes only those observations where we see strictly positive bilateral trade flows. ${ }^{29}$ In our dataset $24.5 \%$ of all possible bilateral trade flows show a zero value. Helpman et. al. argue that this creates a sample selection bias that biases OLS estimates. Moreover, our theoretical model also predicts that the probability of trade between any pair of countries is affected by corruption, nominal tariffs and their interactions. In (9), we can see that a rise in the corruption tax lowers the profits to the exporter. Assuming that the exporter faces a fixed cost of exporting to $d$, associated for example with the maintenance costs of distribution and service networks in the importing country (see Melitz, 2003), we can predict that an increase in the corruption tax (by reducing the potential profits to the exporter) raises the probability that there will be no trade. From this perspective, the econometric model addressing the effect of corruption and nominal tariffs on the probability of trade should be similar to the model used to explain the volume of trade, outlined in (19). Hence we estimate a Heckman selection model, with two questions in mind: first, are the results of the previous section, on the impact of corruption and tariffs on trade flows robust to the correction for selection-bias?; and second, are the effects of the corruption tax on the probability of trade in line with the predictions of our model?

Table 4 presents the results with $T^{M D}$ and $T^{W B}$ - the first and third columns presents the selection equation while the second and fourth show the regression equation. All specifications include importer and exporter fixed-effects. The inverse Mills ratio (not reported) is significant

\footnotetext{
${ }^{29}$ Anderson and van Wincoop (2004), Evenett and Venables (2002), and Haveman and Hummels (2004) also highlight the prevalence of zero bilateral trade flows.
} 
at the $1 \%$, so that the hypothesis of independence of the selection and regression equations for both measure of tariffs is easily rejected. ${ }^{30}$

Column 1 shows that, as expected, the probability of trade is affected by corruption, tariffs and their interaction, in exactly the same way as the volume of trade - we obtain a negative coefficient on corruption and on tariff, and a positive coefficient (and significant) on their interaction and a negative (and significant) coefficient on on tariff* $^{*}$ corruption $^{2}$. More importantly, as column 2 shows, the specification with trade flows yields coefficients for our variables of interest that are similar, in terms of sign, significance and magnitude, to our previous estimates, from using the traditional gravity model (compare column 2 in table 4 to column 4 in table 2). Columns 3 and 4 replicate these results, using the unweighted tariff data $\left(T^{W B}\right)$. Once again, we see that corruption and tariff reduce both the probability and the volume of trade, and that, at high levels of tariff, an increase in corruption has the potential to raise both the probability and the volume of trade. Note that, both interaction terms have the predicted sign and are significant in explaining trade volumes, although tariff* $^{*} \operatorname{corruption}^{2}$ fails to be significant in the selection equation.

In sum, our results give positive answers to the questions raised: the impact of non-linear effects of corruption and tariffs on trade flows obtained in the previous section are robust to controlling for selection bias, and they affect the probability of trade with the same type of nonlinearities.

\subsection{Robustness checks}

This sections looks at a series of alternate specifications to check for the robustness of our results. First, we use the nominal tariff computed by Barro and Lee (1993) for the 1980's; second, we look at the validity of our results for different sub-samples of countries; third, we

\footnotetext{
${ }^{30}$ We rely on the nonlinearity of the inverse Mills ratio for identification of the second-stage equation with trade flows as the dependent variable.
} 
look at an alternative methodology used in the gravity literature that runs the regressions in ratios to account for the price-level in exporting countries; fourth, we use bilateral export fob data to account for the possibility that evasion may undermine the validity of the import data used before.

\subsubsection{Barro-Lee Tariff}

In table 4 , we run our regressions using a weighted average tariff rate $\left(T^{B L}\right)$ calculated in Barro and Lee (1993), where tariffs in each import category is weighted by the fraction of world trade in that category. ${ }^{31}$ This measure is available for a single year in the 1980 s, which means that we cannot use import- or export-country dummies, due to the obvious collinearity with corruption and tariffs. In this sample, the impact of corruption and tariffs emerges solely from the crosscountry variation in the data. We present the OLS estimates for $T^{B L}$ in columns 1 , and the Heckman-corrected estimates in column 2. Our predictions are strongly supported also for this measure of tariffs, in terms of sign and significance.

\subsubsection{Country Sub-samples}

Table 5 presents regression results, taking various permutations in the choice of exporting countries in the sample. Column 1 restricts the sample to high income exporters (using the World Bank classification); column 2 uses middle and low income exporters; column 3 examines exports from OECD countries; column 4 focuses on non-OECD exporters; and, finally, column 5 use only exports from the US. ${ }^{32}$

Our results are remarkably consistent across these various sub-samples - all exporters (rich and poor, OECD and non-OECD) seem to have a similar reaction to tariffs and corruption in the importing country. This stands in contrast to the results of Lamsdorff (1999), who shows

\footnotetext{
31 The variable includes all import charges, such as duties and customs fees.

${ }^{32}$ We present results with import duties as our measure of trade protection. Identical results obtain for $T^{W B}$. Restriciting the sample on the basis of importing country would mean that there would be not enough variation in levels of corruption for us to make inferences.
} 
that only a small subset of exporting countries experience trade diversion due to import country corruption, and that these differences can be explained by differences in their low willingness to offer bribes (as measured by the Bribe Payers Index).

\subsubsection{Ratios to Exports to US}

In table 6, we follow the estimation strategy of Anderson and Marmouiller (2002), who modify the gravity model by using the dependent variable $X_{o d} / X_{o U S}$ (i.e. exports to $d$ relative to exports to the $U S) .{ }^{33}$ This specification has the advantage that all exporter country-specific terms (including any time-variant export-country-specific multilateral trade resistance) cancel out, allowing us to focus on import-country- and pair-specific terms. As in the previous section, we use both measures of tariffs. Columns 1 and 2 report the benchmark model, columns 3 and 4 include country-fixed effects, and columns 5 and 6 do the Heckman correction. ${ }^{34}$

Once again, our predictions are supported. All regressions show a negative coefficient on corruption and the tariff measures, a positive coefficient for their interaction: tariff $*$ corruption, and a negative coefficient for tariff $*$ corruption $^{2}$, all of which are significant. Once again, our expectation that the effect of corruption is contingent on the degree of trade protection is supported. Our results show that, for the $T^{W B}$ measure, at least one third of the observations exhibit a positive relationship between corruption and trade flows. The bulk of these are countries with moderate levels of corruption ( $70 \%$ have corruption indices between 1 and 4) and nearly $80 \%$ of these are more protectionist than the US.

\subsubsection{Exports as dependent variable}

Given that tariff evasion is an integral part of our story, and that one of the ways to evade tariffs is through systematic underreporting of imports, there may be a discrepancy between

\footnotetext{
${ }^{33}$ The formulation imples that the independent variables are also in ratios to the US. For example, corruption $_{d}$ becomes corruption $_{d} /$ corruption $_{U S A}$. See table 1.2 for summary statistics.

${ }^{34}$ Here, we also correct for the case where $X_{o U S}=0$. For brevity, the selection equations are not reported.
} 
reported bilateral imports and actual bilateral imports. In such a scenario, bilateral exports from country $o$ to country $d$ as reported by country $o$ (rather than imports reported by $d$ from o) may be a more accurate measure of the volume of trade flows. Bhagwati (1964) notes these discrepancies in reporting of trade flows by source and destination countries and suggested that evasion of tariffs and other controls could be a potential explanation. Fisman and Wei (2004) find evidence that in the context of Hong Kong-China trade, the evasion gap is higher for sectors that face higher tariffs and VAT. However, others have generally taken these discrepancies to be measurement errors (see, e.g., Feenstra and Hanson 2000). Therefore, as a final robustness check, we use free-on-board exports as the dependent variable. ${ }^{35}$

Table 8 with $T^{M D}$ as the measure of tariffs shows that our predictions are once again supported with this specification. Column 1 shows the results with export and import specific dummies while column 2 corrects the estimates for selection bias. In both cases, the coefficients are significant and have signs as posited. Column 3 shows that using country-pair dummies does not alter our results. The results are very similar with $T^{W B}$ as the measure of tariffs.

\section{Conclusion}

This paper has looked into theory and evidence on the role of corruption as a barrier to trade. Our results, theoretically and empirically, have stressed the nonlinearities of that relationship, and the key role of the interaction with the level of legal protectionism, as set by trade policy. In fact, corruption impedes trade for the vast majority of countries, but, when the degree of regulatory protectionism is high a little bit of corruption can produce an trade enhancing effect. As corruption becomes to strong, its marginal effect is to deter trade. Underlying these nonlinearities are the conflicting roles of corruption in facilitating extortion by customs officials, while, simultaneously, creating an environment prone to the evasion of restrictive regulations.

\footnotetext{
${ }^{35}$ The data on fob exports is much more comprehensive than data on cif exports.
} 
Our results highlight the highly non-linear effects of corruption and their inter-relationship with the extent of regulatory barriers to markets, hence consolidating the various strands of the intellectual history on the effects of corruption.

Moreover, our results have implications for trade and institutional reforms around the world. In fact, the impact of corruption on trade has recently come to the forefront of the trade policy debate, as successive rounds of trade negotiations have reduced traditional trade barriers, such as tariffs and quotas. Trade facilitation discussions have been undertaken at the Doha Round, in an effort to promote transparency, reduce red-tape, and diminish the scope for arbitrary decision-making and cheating. The WTO strongly believes that agreements on trade facilitation will provide a significant boost to world trade. At the same time, countries like Indonesia and the Philippines have recognized the problem of customs corruption and has undertaken serious efforts to eradicate the same.

In this context, our results provide some support to that effort, showing that reducing the scope for corruption does, in the majority of cases, and especially if starting from very high levels, reduce the impediments to trade. However, the results also show that countries that are highly protected, and where levels of corruption are not too high, the right policy is to reduce the level of tariffs, and, more important, that efforts to reduce corruption might have a detrimental effect on trade. An important caveat is raised by Rose-Ackerman (1997), who points out that "tolerating corruption as a way around restrictive trade policies leads to widespread inequities and inefficiencies". Moreover, Kaufmann and Wei (1998) argue that we must also account for the impact of corruption on the regulation itself. Addressing these remains a challenge for future work.

\section{References}

Anderson, J.E. and Mercouiller, D. (2002), "Trade, Insecurity and Home Bias", Review of Economics and Statistics, 84 (2), pp. 345-52. 
Anderson J.E. and Van Wincoop, E. (2004). "Trade Costs", NBER Working Paper No.10480, May.

Anderson J.E. and Van Wincoop, E. (2003). "Gravity with Gravitas: A Solution to the Border Puzzle". The American Economic Review, 93

(1), pp. 170-192.

Anderson, P. S. (1979). "A Theoretical foundation for the gravity equation". American Economic Review, 69, pp. 106-116.

Arduz, M. (2000). "Descripcion y Evaluacion de las Iniciativas Tomadas contra la Corrupcion en el Servicio Nacional de Aduanas en Bolivia". Unpublished case study, OECD Development Centre/UNDP.

Baier S. and Bergstrand J.H. (2001). "The Growth of World Trade: Tariffs, Transport Costs, and Income Similarity". Journal of International Economics, 53 (1), pp. 1-27.

Baldwin, R. E. (2006). "The Euro's Trade Effects," ECB Working Paper 594, March. Studies, Geneva.

Bardhan P. (2006). "The Economist's Approach to the Problem of Corruption", World Development, 34 (2), pp. 341-348.

Barro, R.J. and Lee, J.W. (1993)."International comparisons of educational attainment". Journal of Monetary Economics 32(3), pp. 363-394.

Beck, P. and Maher, M. (1986), "A Comparison of Bribery and Bidding in thin Markets". Economic Letters,20, pp 1-5.

Bergstrand, J. H. (1989). "The generalized gravity equation, monopolistic competition, and the factor-proportions theory in international trade". Review of Economics and Statistics, 71(1), pp. 143-153.

Bhagwati, Jagdish. (1964). "On the Underinvoicing of Imports." Bull. Oxford Univ. Inst. Statis. 26 (November): pp. 389-97.

Davis, D.R. and Weinstein, D.E. (2003). "Market access, Economic Geography and Comparative Advantage: An Empirical Test". Journal of International Economics, 59, pp. $1-23$.

Deardorff A., (1998). "Determinants of Bilateral Trade: Does Gravity Work in Neoclassical World?", in J.A. Frankel (Eds.), The Regionalism of the Economy, NBER Project Report Series, University of Chicago Press.

Evenett, S. J. and Venables, A. (2002). "Export Growth in Developing Countries: Market Entry and Bilateral Trade Flows". Version as of 18 June 2002, Oxford University, mimeo.

Feenstra, R. (2003). Advanced International Trade. Princeton University Press.

Feenstra R. (2002). "Border Effects and the Gravity Equation: Consistent Methods for Estimation". Scottish Journal of Political Economy, 49 (5), pp. 491-506.

Feenstra, R., and Hanson, G.H. (2000). "Aggregation Bias in the Factor Content of Trade: Evidence from U.S. Manufacturing." American Economic Review Papers and Proceedings, 90, pp. $155-60$. 
Fisman, R. and Wei, S. (2004). "Tax Rates and Tax Evasion: Evidence from "Missing Imports" in China". Journal of Political Economy, 112(2), pp. 471-496.

Francois, J. and Manchin, M. (2007). "Institutions, Infrastructure and Trade," CEPR Discussion Papers 6068.

Frankel, J. (1997), "Regional Trading Blocs in the World Trading System". Institute for International Economics, Washington DC.

Frankel, J. A. and Rose A.K. (2000). "Estimating the Effect of Currency Unions on Trade and Growth". National Bureau of Economic Research Working Paper 7857

Glick, R. and Rose, A. (2002). Does a currency union affect trade ? The time series evidence, European Economic Review 46 (6), pp.1125-51.

Gould, D. M. (1994). "Immigrant Links to Home Country: Empirical Implications for US bilateral trade flows" The Review of Economics and Statistics 76, pp. 302-316.

Harrigan, J. (1996). "Technology, factor supplies, and international specialization: estimating the neo-classical model". American Economic Review, 87, 4, 475-94.

Haveman, J. and Hummels, D. (2004). "Alternative Hypotheses and the Volume of Trade: The Gravity Equation and the Extent of Specialization". Canadian Journal of Economics, 37 (1), pp. 199-218.

Helpman, E., Melitz, M. and Rubinstein, Y. (2006): "Trading Partners and Trading Volumes," Discussion paper, Harvard University.

Henisz, W. J. (2000). "The Institutional Environment for Economic Growth." Economics and Politics 12(1), pp. 1-3.

Hummels, D. (1999). "Towards A Geography of Trade Costs". University of Chicago. Mimeo document.

Huntington, S. P. (1968). Political order in changing societies. New Haven: Yale U. Press.

Kaufmann, D. and Wei, S.J. (1998). "Does "Grease Payment' Speed Up the Wheels of Commerce?" World Bank and Harvard University, mimeo.

Knack, S. and Keefer, P. (1995). "Institutions and Economic Performance: Cross-Country Tests Using Alternative Institutional Measures". Economics and Politics 7(3), pp.207-227.

Lambsdorff, J. (1999). "Corruption in Empirical Research - A Review", TI Working Paper, Transparency International, Berlin.

Leff, N. H. (1964). "Economic Development through Bureaucratic Corruption," The American Behavioral Scientist, 8(2), pp. 8-14.

Lui, F.T. (1985). "An Equilibrium Queuing Model of Bribery". Journal of Political Economy, 93 (4), pp. 760-781.

Martin, P., T. Mayer, and Thoenig, M. (2006). "Make Trade not War?", CEPR DP 5218.

Mauro, P. (1998). "Corruption and the Composition of Government Expenditure". Journal of Public Economics, 69,pp. 263-279. 
Mauro, P. (1995). "Corruption and growth". Quarterly Journal of Economics, 110, pp. 681-712.

McCallum J. (1995). "National Borders Matter : Canada-US Regional Trade Patterns". American Economic Review, 85(3), pp. 615-623.

Melitz, M. J. (2003). "The impact of trade on aggregate industry productivity and intraindustry reallocations", Econometrica 71(6), pp.1695-1725.

Neumann, P.(1994). "Bose: Fast Alle Bestechen," Impulse, pp. 12-6.

Parayno, G. (1999). "Reforming the Philippines Customs Service through Electronic Governance". In Combating Corruption in Asian and Pacific Economies. Manila: Asian Development Bank and Organization for European Cooperation and Development.

Persson, T. (2001). "Currency Union and Trade: How large is the Treatment Effect?, Economic Policy, 16 (33), pp. 435-448.

Princeton Survey Research Associates (PSRA) (2003). The Global Poll: Multinational Survey of Opinion Leaders 2002. Full Report, prepared for the World Bank. http://siteresources.worldbank.org

Rodrik D. and Rodriguez F. (2000), "Trade Policy and Economic Growth: A Skeptic's Guide to the Cross-National Evidence," in B. Bernanke et K. Rogoff, NBER Macroeconomics Annual, Cambridge, MA, MIT Press.

Rose-Ackerman, R. (1997). "The political economy of corruption". In K.A. Elliott (Ed.), Corruption and the global economy, 31-60. Washington DC: Institute for International Economics.

Rose, Andrew K. (2004). "Do We Really Know That the WTO Increases Trade?". American Economic Review 94 (1), pp. 98-114.

Rose, Andrew K. (2004). "Does the WTO Make Trade More Stable?," CEPR Discussion Papers 4246, C.E.P.R. Discussion Papers.

Rose, Andrew K. (2000). "One Money One Market". Economic Policy, 30, 7-46.

Rose, Andrew K. and Wincoop, E. (2001). "National Money as a Barrier to International Trade: The Real Case for Currency Union". American Economic Review, 91(2), pp. 386-3.

Subramanian, A. and Wei, S.J. (2003). "The WTO Promotes Trade, Strongly but Unevenly". IMF Working Papers 03/185, International Monetary Fund.

Tanzi, V., and Davoodi, H. (1997). "Corruption, Public Investment, and Growth". IMF Working Paper WP/97/139.

Wei, S. (2000). "How taxing is corruption on international investors?". The Review of Economics and Statistics 82, pp.1-11.

Younas, M.M. (2000). "Fighting Corruption in Pakistan Customs Administration". unpublished case study, OECD Development Centre/UNDP. 
Table 1.1: Summary Statistics

\begin{tabular}{llll}
\hline Variable & \multicolumn{1}{c}{$N$} & Mean & Std. Dev. \\
\hline Import dummy & 601055 & 0.57 & 0.49 \\
Log of imports & 343541 & 1.23 & 3.22 \\
Import Duty ( $T^{M D}$ ) & 345239 & 0.08 & 0.12 \\
Unweighted Tariffs $\left(T^{W B}\right)$ & 316905 & 0.15 & 0.13 \\
Weighted Tariffs $\left(T^{\mathrm{BL}}\right)$ & 14018 & 0.17 & 0.18 \\
Corruption (importer) & 434130 & 2.75 & 1.43 \\
Corruption (exporter) & 435866 & 2.75 & 1.44 \\
log GDP (exporter) & 565338 & 23.33 & 2.33 \\
log GDP (importer) & 566996 & 23.31 & 2.34 \\
Log distance & 618533 & 8.72 & 0.8 \\
Contiguous & 618533 & 0.02 & 0.14 \\
Common official language & 618533 & 0.18 & 0.38 \\
Linguistic similarity & 618533 & 0.17 & 0.38 \\
Colonial link & 618533 & 0.01 & 0.12 \\
Common colonizer & 618533 & 0.12 & 0.32 \\
Same country & 618533 & 0.01 & 0.1 \\
Both in GATT/WTO & 546087 & 0.5 & 0.5 \\
One in GATT/WTO & 600648 & 0.93 & 0.25 \\
Polity (exporter) & 444823 & 1.57 & 7.49 \\
Polity (importer) & 442878 & 1.62 & 7.49 \\
Political constraints (exporter) & 322948 & 0.42 & 0.34 \\
Political constraints (importer) & 323871 & 0.42 & 0.34 \\
Exporter price & 574977 & 3.86 & 0.61 \\
Importer price & 574919 & 3.87 & 0.61 \\
\hline
\end{tabular}

\section{Table 1.2: Summary Statistics (ratios)}

\begin{tabular}{llll}
\hline Variable & $N$ & Mean & Std. Dev. \\
\hline Import dummy & 594487 & 0.55 & 0.5 \\
Log of Import ratio & 329637 & -5.09 & 3.32 \\
Corruption ratio (importer) & 430288 & 1.74 & 0.94 \\
Import Duty ratio & 318577 & 1.06 & 0.12 \\
Unweighted Tariff ratio & 263533 & 1.08 & 0.1 \\
log GDP ratio (importer) & 561436 & -6.17 & 2.34 \\
Log distance ratio & 612332 & -0.2 & 0.94 \\
Contiguous ratio & 612332 & 0 & 0.12 \\
Common official language ratio & 612332 & -0.09 & 0.35 \\
Linguistic similarity ratio & 612332 & -0.18 & 0.36 \\
Colonial link ratio & 612332 & -0.01 & 0.13 \\
Common colonizer ratio & 612332 & 0.08 & 0.23 \\
Same country ratio & 612332 & 0.01 & 0.07 \\
Both in GATT/WTO ratio & 529690 & -0.14 & 0.27 \\
One in GATT/WTO ratio & 594800 & -0.05 & 0.18 \\
Polity ratio & 438425 & 0.16 & 0.75 \\
Political constraints ratio & 320592 & 0.49 & 0.4 \\
Importer price ratio & 569251 & -0.74 & 0.61 \\
\hline
\end{tabular}


Table 2: Effect of Corruption and Import Duty on Bilateral Imports ${ }^{\mathrm{a}}$

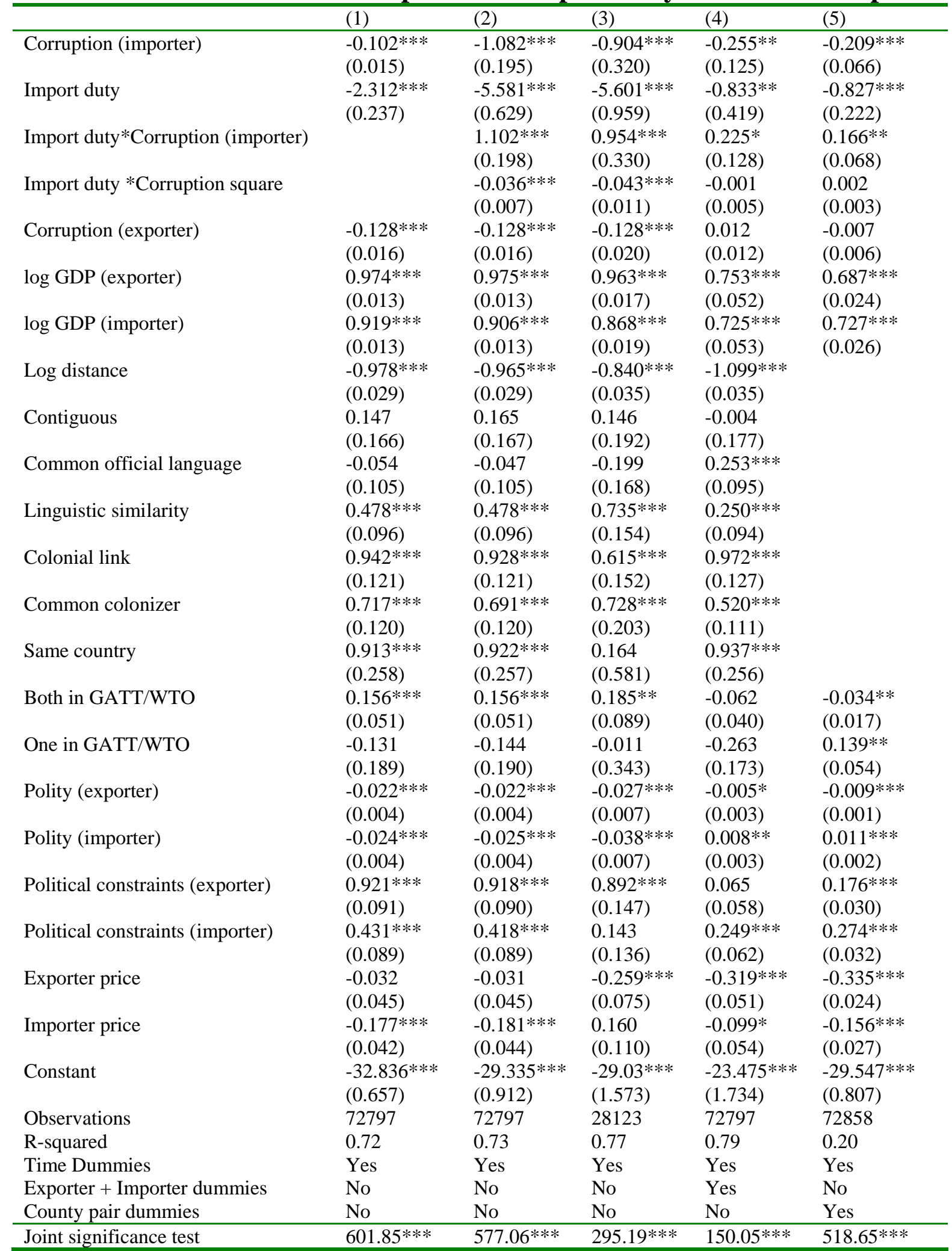

Standard errors adjusted for clustering on country-pairs; * significant at $10 \%$; ** significant at $5 \%$; *** significant at $1 \%$ a: Column 3 uses export and import unit values as proxies for exporter and importer price; all others use GDP deflators. Column 4 and 5 use country fixed effects and country-pair fixed effects respectively. 
Table 3: Effect of Corruption and Unweighted Average Tariffs on Bilateral Imports ${ }^{\mathrm{a}}$

\begin{tabular}{|c|c|c|c|c|c|}
\hline & $(1)$ & $(2)$ & (3) & (4) & (5) \\
\hline \multirow[t]{2}{*}{ Corruption (importer) } & $-0.051 * * *$ & $-0.128 * * *$ & $-0.138 * * *$ & $-0.034 * *$ & $-0.034 * * *$ \\
\hline & $(0.015)$ & $(0.024)$ & $(0.033)$ & $(0.017)$ & $(0.010)$ \\
\hline \multirow[t]{2}{*}{ Unweighted Tariffs } & $-1.400 * * *$ & $-4.763 * * *$ & $-6.775 * * *$ & $-0.832 *$ & $-0.522 *$ \\
\hline & $(0.171)$ & $(0.809)$ & $(1.168)$ & $(0.505)$ & $(0.277)$ \\
\hline \multirow{2}{*}{$\begin{array}{l}\text { Unweighted Tariffs*Corruption } \\
\text { (importer) }\end{array}$} & & $1.408 * * *$ & $2.218 * * *$ & 0.257 & 0.008 \\
\hline & & $(0.386)$ & $(0.587)$ & $(0.236)$ & $(0.136)$ \\
\hline \multirow[t]{2}{*}{ Unweighted Tariff*Corruption square } & & $-0.128 * * *$ & $-0.206 * * *$ & -0.026 & 0.014 \\
\hline & & $(0.043)$ & $(0.066)$ & $(0.027)$ & $(0.016)$ \\
\hline \multirow[t]{2}{*}{ Corruption (exporter) } & $-0.096 * * *$ & $-0.096 * * *$ & $-0.075^{* * *}$ & $-0.035 * * *$ & $-0.032 * * *$ \\
\hline & $(0.017)$ & $(0.017)$ & $(0.021)$ & $(0.013)$ & $(0.007)$ \\
\hline \multirow[t]{2}{*}{ log GDP (exporter) } & $1.012^{* * *}$ & $1.013^{* * *}$ & $0.994 * * *$ & $0.733^{* * * *}$ & $0.663 * * *$ \\
\hline & $(0.013)$ & $(0.013)$ & $(0.018)$ & $(0.068)$ & $(0.030)$ \\
\hline \multirow[t]{2}{*}{ log GDP (importer) } & $0.937 * * *$ & $0.935^{* * *}$ & $0.878 * * *$ & $0.762 * * *$ & $0.758 * * *$ \\
\hline & $(0.012)$ & $(0.012)$ & $(0.019)$ & $(0.053)$ & $(0.028)$ \\
\hline \multirow[t]{2}{*}{ Log distance } & $-1.029 * * *$ & $-1.025 * * *$ & $-0.887 * * *$ & $-1.166^{* * *}$ & \\
\hline & $(0.030)$ & $(0.030)$ & $(0.038)$ & $(0.035)$ & \\
\hline \multirow[t]{2}{*}{ Contiguous } & $0.524 * * *$ & $0.552^{* * *}$ & 0.214 & $0.368 * *$ & \\
\hline & $(0.154)$ & $(0.155)$ & $(0.201)$ & $(0.162)$ & \\
\hline \multirow[t]{2}{*}{ Common official language } & -0.013 & -0.008 & -0.142 & $0.264 * * *$ & \\
\hline & $(0.098)$ & $(0.098)$ & $(0.163)$ & $(0.089)$ & \\
\hline \multirow[t]{2}{*}{ Linguistic similarity } & $0.453 * * *$ & $0.452 * * *$ & $0.736 * * *$ & $0.273^{* * *}$ & \\
\hline & $(0.090)$ & $(0.090)$ & $(0.147)$ & $(0.090)$ & \\
\hline \multirow[t]{2}{*}{ Colonial link } & $0.894 * * *$ & $0.886^{* * *}$ & $0.456 * * *$ & $0.924 * * *$ & \\
\hline & $(0.121)$ & $(0.121)$ & $(0.157)$ & $(0.130)$ & \\
\hline \multirow[t]{2}{*}{ Common colonizer } & $0.750 * * *$ & $0.739 * * *$ & $0.789 * * *$ & $0.523 * * *$ & \\
\hline & $(0.110)$ & $(0.109)$ & $(0.217)$ & $(0.101)$ & \\
\hline \multirow[t]{2}{*}{ Same country } & $0.736^{* * *}$ & $0.733 * * *$ & 0.118 & $0.786 * * *$ & \\
\hline & $(0.236)$ & $(0.238)$ & $(0.580)$ & $(0.233)$ & \\
\hline \multirow[t]{2}{*}{ Both in GATT/WTO } & $0.141 * *$ & $0.133^{* *}$ & 0.081 & $-0.106^{* *}$ & $-0.109 * * *$ \\
\hline & $(0.055)$ & $(0.055)$ & $(0.093)$ & $(0.042)$ & $(0.020)$ \\
\hline \multirow[t]{2}{*}{ One in GATT/WTO } & -0.138 & -0.141 & 0.157 & $-0.341^{* *}$ & -0.010 \\
\hline & $(0.167)$ & $(0.167)$ & $(0.303)$ & $(0.153)$ & $(0.061)$ \\
\hline \multirow[t]{2}{*}{ Polity (exporter) } & $-0.020 * * *$ & $-0.020 * * *$ & $-0.027 * * *$ & $-0.012 * * *$ & $-0.011 * * *$ \\
\hline & $(0.005)$ & $(0.005)$ & $(0.008)$ & $(0.004)$ & $(0.002)$ \\
\hline \multirow[t]{2}{*}{ Polity (importer) } & $-0.018 * * *$ & $-0.019 * * *$ & $-0.035 * * *$ & 0.003 & $0.008 * * *$ \\
\hline & $(0.004)$ & $(0.004)$ & $(0.007)$ & $(0.003)$ & $(0.002)$ \\
\hline \multirow[t]{2}{*}{ Political constraints (exporter) } & $0.997 * * *$ & $0.996 * * *$ & $1.094 * * *$ & $0.174^{* * *}$ & $0.177^{* * *}$ \\
\hline & $(0.089)$ & $(0.089)$ & $(0.164)$ & $(0.065)$ & $(0.033)$ \\
\hline \multirow[t]{2}{*}{ Political constraints (importer) } & $0.388 * * *$ & $0.408^{* * *}$ & $0.405^{* * *}$ & -0.019 & -0.022 \\
\hline & $(0.083)$ & $(0.082)$ & $(0.140)$ & $(0.060)$ & $(0.033)$ \\
\hline Exporter price & -0.020 & -0.018 & $-0.251 * *$ & $-0.535^{* * *}$ & $-0.478^{* * *}$ \\
\hline & $(0.046)$ & $(0.046)$ & $(0.107)$ & $(0.069)$ & $(0.031)$ \\
\hline Importer price & $-0.106 * *$ & $-0.158^{* * *}$ & -0.049 & 0.061 & 0.034 \\
\hline & $(0.044)$ & $(0.045)$ & $(0.142)$ & $(0.050)$ & $(0.027)$ \\
\hline Constant & $-35.628 * * *$ & $-35.143^{* * *}$ & $-33.710 * * *$ & $-19.098 * * *$ & $-30.725 * * *$ \\
\hline & $(0.562)$ & $(0.560)$ & $(1.220)$ & $(2.265)$ & $(0.885)$ \\
\hline Observations & 59357 & 59357 & 19914 & 59357 & 59405 \\
\hline R-squared & 0.72 & 0.72 & 0.78 & 0.79 & 0.19 \\
\hline Time Dummies & Yes & Yes & Yes & Yes & Yes \\
\hline Exporter+Importer dummies & No & No & No & Yes & No \\
\hline Country pair dummies & No & No & No & No & Yes \\
\hline Joint significance test & $608.79 * * *$ & $578.46 * * *$ & $262.29 * * *$ & $156.02 * * *$ & $364.97 * * *$ \\
\hline
\end{tabular}

Standard errors adjusted for clustering on country-pairs; * significant at $10 \%$; ** significant at $5 \%$; *** significant at $1 \%$ a: Column 3 uses export and import unit values as proxies for exporter and importer price; all others use GDP deflators. Column 4 and 5 use country fixed effects and country-pair fixed effects respectively. 
Table 4: Effect of Corruption and Tariffs on Bilateral Imports: Heckman Model Estimates ${ }^{\mathrm{a}}$

\begin{tabular}{|c|c|c|c|c|}
\hline & $(1)$ & $(2)$ & (3) & (4) \\
\hline & Import Duty & Import Duty & Unweighted tariff & Unweighted tariff \\
\hline & Prob & $M_{i j}$ & Prob & $M_{i j}$ \\
\hline \multirow[t]{2}{*}{ Corruption (importer) } & -0.117 & $-0.260 * *$ & $-0.121 * * *$ & $-0.028 *$ \\
\hline & $(0.106)$ & $(0.102)$ & $(0.018)$ & $(0.015)$ \\
\hline \multirow[t]{2}{*}{ Tariffs } & $-1.795 * * *$ & $-0.791^{* *}$ & $-1.750 * * *$ & $-0.994^{* *}$ \\
\hline & $(0.349)$ & $(0.340)$ & $(0.451)$ & $(0.422)$ \\
\hline \multirow[t]{2}{*}{ Tariffs*Corruption (importer) } & $0.239 * *$ & $0.229 * *$ & $0.382^{*}$ & $0.415^{* *}$ \\
\hline & $(0.105)$ & $(0.104)$ & $(0.220)$ & $(0.205)$ \\
\hline \multirow[t]{2}{*}{ Tariff*Corruption square } & $-0.016 * * *$ & -0.001 & -0.001 & $-0.048 * *$ \\
\hline & $(0.005)$ & $(0.004)$ & $(0.025)$ & $(0.024)$ \\
\hline \multirow[t]{2}{*}{ Corruption (exporter) } & $-0.018^{*}$ & 0.014 & -0.011 & $-0.026^{* *}$ \\
\hline & $(0.011)$ & $(0.009)$ & $(0.011)$ & $(0.011)$ \\
\hline \multirow[t]{2}{*}{$\log$ GDP (exporter) } & -0.005 & $0.754 * * *$ & $0.102 * * *$ & $0.751 * * *$ \\
\hline & $(0.036)$ & $(0.036)$ & $(0.039)$ & $(0.044)$ \\
\hline \multirow[t]{2}{*}{ log GDP (importer) } & $0.079 * *$ & $0.720 * * *$ & $0.209 * * *$ & $1.020 * * *$ \\
\hline & $(0.039)$ & $(0.040)$ & $(0.028)$ & $(0.027)$ \\
\hline \multirow[t]{2}{*}{ Log distance } & $-0.866 * * *$ & $-1.093 * * *$ & $-0.883 * * *$ & $-1.133^{* * *}$ \\
\hline & $(0.015)$ & $(0.009)$ & $(0.016)$ & $(0.011)$ \\
\hline \multirow[t]{2}{*}{ Contiguous } & $0.152 * *$ & 0.020 & $0.120^{*}$ & $0.381^{* * *}$ \\
\hline & $(0.069)$ & $(0.038)$ & $(0.065)$ & $(0.042)$ \\
\hline \multirow[t]{2}{*}{ Common official language } & $0.425 * * *$ & $0.229 * * *$ & $0.435 * * *$ & $0.197 * * *$ \\
\hline & $(0.033)$ & $(0.030)$ & $(0.034)$ & $(0.033)$ \\
\hline \multirow[t]{2}{*}{ Linguistic similarity } & -0.052 & $0.241 * * *$ & $-0.068 * *$ & $0.253 * * *$ \\
\hline & $(0.032)$ & $(0.029)$ & $(0.034)$ & $(0.032)$ \\
\hline \multirow[t]{2}{*}{ Colonial link } & 0.192 & $0.973 * * *$ & -0.081 & $0.944 * * *$ \\
\hline & $(0.152)$ & $(0.036)$ & $(0.163)$ & $(0.043)$ \\
\hline \multirow[t]{2}{*}{ Common colonizer } & $0.281^{* * *}$ & $0.524 * * *$ & $0.297 * * *$ & $0.496 * * *$ \\
\hline & $(0.029)$ & $(0.030)$ & $(0.030)$ & $(0.031)$ \\
\hline \multirow[t]{2}{*}{ Same country } & $0.458 * * *$ & $0.885^{* * *}$ & $0.436 * * *$ & $0.692 * * *$ \\
\hline & $(0.095)$ & $(0.054)$ & $(0.092)$ & $(0.056)$ \\
\hline \multirow{2}{*}{ Both in GATT/WTO } & $0.108 * * *$ & $-0.062 * *$ & 0.029 & $-0.122 * * *$ \\
\hline & $(0.025)$ & $(0.025)$ & $(0.027)$ & $(0.029)$ \\
\hline \multirow[t]{2}{*}{ One in GATT/WTO } & $0.103^{* *}$ & $-0.298 * * *$ & $0.156^{* * *}$ & $-0.430 * * *$ \\
\hline & $(0.046)$ & $(0.061)$ & $(0.054)$ & $(0.076)$ \\
\hline \multirow[t]{2}{*}{ Polity (exporter) } & $-0.008^{* * *}$ & $-0.005^{* *}$ & $-0.008 * * *$ & $-0.012 * * *$ \\
\hline & $(0.002)$ & $(0.002)$ & $(0.002)$ & $(0.003)$ \\
\hline \multirow[t]{2}{*}{ Polity (importer) } & $0.010 * * *$ & $0.008 * * *$ & $0.009 * * *$ & 0.003 \\
\hline & $(0.003)$ & $(0.003)$ & $(0.003)$ & $(0.003)$ \\
\hline \multirow{2}{*}{ Political constraints (exporter) } & $0.146^{* * *}$ & 0.057 & $0.174 * * *$ & $0.137 * * *$ \\
\hline & $(0.049)$ & $(0.045)$ & $(0.049)$ & $(0.050)$ \\
\hline \multirow[t]{2}{*}{ Political constraints (importer) } & $-0.145^{* * *}$ & $0.253^{*} * *$ & $0.214^{* * *}$ & $-0.082 *$ \\
\hline & $(0.050)$ & $(0.049)$ & $(0.049)$ & $(0.049)$ \\
\hline Exporter price & $-0.108^{* * *}$ & $-0.310 * * *$ & $-0.125 * * *$ & $-0.491 * * *$ \\
\hline & $(0.035)$ & $(0.036)$ & $(0.039)$ & $(0.046)$ \\
\hline Importer price & $-0.285 * * *$ & $-0.085^{* *}$ & $-0.251^{* * *}$ & -0.049 \\
\hline & $(0.040)$ & $(0.042)$ & $(0.033)$ & $(0.035)$ \\
\hline Constant & $6.442 * * *$ & $-23.282 * * *$ & 0.149 & $-29.040 * * *$ \\
\hline & (1.149) & $(1.156)$ & $(0.910)$ & $(0.927)$ \\
\hline Observations (uncensored) & 94700 & 94700 & 78583 & 78583 \\
\hline Time Dummies & Yes & Yes & Yes & Yes \\
\hline Exporter + Importer dummies & Yes & Yes & Yes & Yes \\
\hline Joint significance test & & $211801.97 * * *$ & & $135205.98 * * *$ \\
\hline
\end{tabular}

Standard errors adjusted for clustering on country-pairs;* significant at $10 \%$; ** significant at $5 \%$; *** significant at $1 \%$ a: All columns use GDP deflators and country fixed effects; Columns 1 and 3 estimate the probability of trading relationship between country pairs; columns 2 and 4 show the Heckman corrected gravity estimates 
Table 5: Effect of Corruption and Barro-Lee Measure of Protection (Weighted Tariffs) on Bilateral Imports ${ }^{\mathrm{a}}$

\begin{tabular}{|c|c|c|}
\hline & $(1)$ & $(2)$ \\
\hline & OLS & Heckman \\
\hline \multirow[t]{2}{*}{ Corruption (importer) } & $-0.196 * * *$ & $-0.190 * * *$ \\
\hline & $(0.036)$ & $(0.035)$ \\
\hline \multirow[t]{2}{*}{ Weighted Tariffs } & $-3.835 * * *$ & $-3.672 * * *$ \\
\hline & $(1.177)$ & $(1.068)$ \\
\hline \multirow[t]{2}{*}{ Weighted Tariffs*Corruption (importer) } & $1.477 * *$ & $1.415^{* * *}$ \\
\hline & $(0.582)$ & $(0.530)$ \\
\hline \multirow{2}{*}{ Weighted Tariff*Corruption square } & $-0.164 * *$ & $-0.159 * *$ \\
\hline & $(0.070)$ & $(0.065)$ \\
\hline \multirow[t]{2}{*}{ Corruption (exporter) } & $-0.204 * * *$ & $-0.206 * * *$ \\
\hline & $(0.028)$ & $(0.025)$ \\
\hline \multirow[t]{2}{*}{$\log$ GDP (exporter) } & $0.847 * * *$ & $0.838 * * *$ \\
\hline & $(0.020)$ & $(0.020)$ \\
\hline \multirow[t]{2}{*}{ log GDP (importer) } & $0.859 * * *$ & $0.853 * * *$ \\
\hline & $(0.020)$ & $(0.021)$ \\
\hline \multirow[t]{2}{*}{ Log distance } & $-0.926 * * *$ & $-0.918^{* * *}$ \\
\hline & $(0.038)$ & $(0.038)$ \\
\hline \multirow[t]{2}{*}{ Contiguous } & 0.274 & $0.290 *$ \\
\hline & $(0.178)$ & $(0.166)$ \\
\hline \multirow[t]{2}{*}{ Common official language } & -0.087 & -0.102 \\
\hline & $(0.139)$ & $(0.128)$ \\
\hline \multirow[t]{2}{*}{ Linguistic similarity } & $0.385^{* * *}$ & $0.393 * * *$ \\
\hline & $(0.128)$ & $(0.121)$ \\
\hline \multirow[t]{2}{*}{ Colonial link } & $1.101^{* * *}$ & $1.092 * * *$ \\
\hline & $(0.130)$ & $(0.153)$ \\
\hline \multirow{2}{*}{ Common colonizer } & $0.504 * * *$ & $0.506 * * *$ \\
\hline & $(0.161)$ & $(0.126)$ \\
\hline \multirow[t]{2}{*}{ Same country } & $1.086 * * *$ & $1.039 * * *$ \\
\hline & $(0.293)$ & $(0.238)$ \\
\hline \multirow[t]{2}{*}{ Both in GATT/WTO } & $0.396 * * *$ & $0.390 * * *$ \\
\hline & $(0.069)$ & $(0.061)$ \\
\hline \multirow[t]{2}{*}{ One in GATT/WTO } & 0.079 & 0.057 \\
\hline & $(0.213)$ & $(0.173)$ \\
\hline \multirow[t]{2}{*}{ Polity (exporter) } & $-0.040 * * *$ & $-0.040 * * *$ \\
\hline & $(0.007)$ & $(0.007)$ \\
\hline \multirow[t]{2}{*}{ Polity (importer) } & $-0.034^{* * *}$ & $-0.035 * * *$ \\
\hline & $(0.008)$ & $(0.007)$ \\
\hline \multirow[t]{2}{*}{ Political constraints (exporter) } & $1.484 * * *$ & $1.445^{* * * *}$ \\
\hline & $(0.191)$ & $(0.178)$ \\
\hline \multirow[t]{2}{*}{ Political constraints (importer) } & $0.870 * * *$ & $0.866^{* * * *}$ \\
\hline & $(0.207)$ & $(0.189)$ \\
\hline \multirow[t]{2}{*}{ Exporter price } & $-0.248 * *$ & $-0.246 * * *$ \\
\hline & $(0.102)$ & $(0.079)$ \\
\hline \multirow[t]{2}{*}{ Importer price } & $-0.234^{* *}$ & $-0.226 * * *$ \\
\hline & $(0.092)$ & $(0.085)$ \\
\hline Constant & $-29.290 * * *$ & $-28.969 * * *$ \\
\hline & $(0.943)$ & $(0.866)$ \\
\hline Observations & 3986 & 5595 \\
\hline$R^{2}$ & 0.70 & 0.70 \\
\hline Joint significan & 449.64 & 6248.48 \\
\hline
\end{tabular}

Standard errors adjusted for clustering on country-pairs;* significant at 10\%; ** significant at 5\%; *** significant at $1 \%$ a: All columns use GDP deflators; Columns 1 shows the OLS gravity estimates; columns 2 shows the Heckman corrected gravity estimates 
Table 6: Effect of Corruption and Import Duties on Bilateral Imports: Sub Sample Robustness Checks

\begin{tabular}{|c|c|c|c|c|c|}
\hline & $(1)$ & $(2)$ & (3) & (4) & (5) \\
\hline & $\begin{array}{l}\text { High Income } \\
\text { Exporter }\end{array}$ & $\begin{array}{l}\text { Middle Low } \\
\text { Income } \\
\text { Exporter }\end{array}$ & $O E C D$ & Non-OECD & $\begin{array}{l}\text { Exports from } \\
\text { USA }\end{array}$ \\
\hline Corruption (importer) & $\begin{array}{l}-0.251^{* *} \\
(0.099)\end{array}$ & $\begin{array}{l}-0.341^{* *} \\
(0.149)\end{array}$ & $\begin{array}{l}-0.217 * * \\
(0.101)\end{array}$ & $\begin{array}{l}-0.360 * * \\
(0.144)\end{array}$ & $\begin{array}{l}-0.643^{* * * *} \\
(0.164)\end{array}$ \\
\hline Tariffs & $\begin{array}{l}-0.654^{* *} \\
(0.330)\end{array}$ & $\begin{array}{l}-1.177^{* *} \\
(0.500)\end{array}$ & $\begin{array}{l}-0.490 \\
(0.335)\end{array}$ & $\begin{array}{l}-1.276^{* * *} \\
(0.485)\end{array}$ & $\begin{array}{l}-1.997 * * * \\
(0.540)\end{array}$ \\
\hline Tariffs*Corruption (importer) & $\begin{array}{l}0.244^{* *} \\
(0.101)\end{array}$ & $\begin{array}{l}0.297^{*} \\
(0.153)\end{array}$ & $\begin{array}{l}0.199 * \\
(0.103)\end{array}$ & $\begin{array}{l}0.325^{* *} \\
(0.148)\end{array}$ & $\begin{array}{l}0.733 * * * \\
(0.167)\end{array}$ \\
\hline Tariff*Corruption square & $\begin{array}{l}-0.001 \\
(0.004)\end{array}$ & $\begin{array}{l}-0.002 \\
(0.006)\end{array}$ & $\begin{array}{l}0.001 \\
(0.004)\end{array}$ & $\begin{array}{l}-0.004 \\
(0.006)\end{array}$ & $\begin{array}{l}-0.015^{* *} \\
(0.007)\end{array}$ \\
\hline Corruption (exporter) & $\begin{array}{l}-0.012 \\
(0.011)\end{array}$ & $\begin{array}{l}0.028 * * \\
(0.013)\end{array}$ & $\begin{array}{l}-0.013 \\
(0.011)\end{array}$ & $\begin{array}{l}0.031^{* *} \\
(0.012)\end{array}$ & \\
\hline Observations & 26933 & 45864 & 25010 & 47787 & 1138 \\
\hline R-squared & 0.89 & 0.69 & 0.90 & 0.70 & 0.98 \\
\hline Time Dummies & Yes & Yes & Yes & Yes & Yes \\
\hline Exporter + Importer Dummies & Yes & Yes & Yes & Yes & Yes \\
\hline Joint significance test & $1574.44 * * *$ & $540.60 * * *$ & $1557.05^{* * *}$ & $578.16 * * *$ & $436.56 * * *$ \\
\hline
\end{tabular}

Regressions include all variable from the model 1 in table 1 (not reported). Import Duty is the tariff measure used. All columns use GDP deflators and country fixed effects.

Standard errors adjusted for clustering on country-pairs;* significant at $10 \%$; ** significant at $5 \%$; *** significant at $1 \%$ 
Table 7: Effect of Corruption and Tariffs on Bilateral Imports: All Variables in Ratios with USA as Base Country

\begin{tabular}{|c|c|c|c|c|c|c|}
\hline & (1) & $(2)$ & (3) & (4) & (5) & $(6)$ \\
\hline & OLS & OLS & OLS & OLS & Heckman & Heckman \\
\hline & Import Duty & $\begin{array}{l}\text { Unweighted } \\
\text { tariff }\end{array}$ & Import Duty & $\begin{array}{l}\text { Unweighted } \\
\text { tariff }\end{array}$ & Import Duty & $\begin{array}{l}\text { Unweighted } \\
\text { tariff }\end{array}$ \\
\hline \multirow{2}{*}{ Corruption (importer) } & $-1.169 * * *$ & $-2.136 * * *$ & $-0.732 * * *$ & $-0.932 * * *$ & $-0.713^{* * *}$ & $-0.912 * * *$ \\
\hline & $(0.108)$ & $(0.155)$ & $(0.125)$ & $(0.190)$ & $(0.126)$ & $(0.191)$ \\
\hline \multirow[t]{2}{*}{ Tariff } & $-4.648 * * *$ & $-5.945 * * *$ & $-1.796 * * *$ & $-3.080 * * *$ & $-1.560 * * *$ & $-2.934 * * *$ \\
\hline & $(0.262)$ & $(0.345)$ & $(0.336)$ & $(0.455)$ & $(0.342)$ & $(0.460)$ \\
\hline \multirow[t]{2}{*}{ Tariffs*Corruption (importer) } & $1.035 * * *$ & $2.563 * * *$ & $0.646 * * *$ & $1.125 * * *$ & $0.613 * * *$ & $1.141^{* * *}$ \\
\hline & $(0.112)$ & $(0.192)$ & $(0.129)$ & $(0.243)$ & $(0.130)$ & $(0.243)$ \\
\hline \multirow[t]{2}{*}{ Tariff*Corruption square } & $-0.014 * * *$ & $-0.214^{* * * *}$ & -0.001 & $-0.086^{* * *}$ & 0.001 & $-0.096 * * *$ \\
\hline & $(0.004)$ & $(0.020)$ & $(0.005)$ & $(0.030)$ & $(0.005)$ & $(0.030)$ \\
\hline \multirow[t]{2}{*}{$\log$ GDP (importer) } & $0.936 * * *$ & $0.939 * * *$ & $0.695 * * *$ & $0.574 * * *$ & $0.667 * * *$ & $0.566 * * *$ \\
\hline & $(0.005)$ & $(0.006)$ & $(0.053)$ & $(0.067)$ & $(0.054)$ & $(0.067)$ \\
\hline \multirow[t]{2}{*}{ Log distance } & $-1.110 * * *$ & $-1.062 * * *$ & $-1.065 * * *$ & $-1.041 * * *$ & $-0.998 * * *$ & $-1.010 * * *$ \\
\hline & $(0.009)$ & $(0.010)$ & $(0.009)$ & $(0.011)$ & $(0.017)$ & $(0.018)$ \\
\hline \multirow[t]{2}{*}{ Contiguous } & $0.204^{* * *}$ & $0.743 * * *$ & $0.443 * * *$ & $0.885^{* * *}$ & $0.635 * * *$ & $0.969 * * *$ \\
\hline & $(0.052)$ & $(0.063)$ & $(0.051)$ & $(0.063)$ & $(0.066)$ & $(0.074)$ \\
\hline \multirow[t]{2}{*}{ Common official language } & $0.147 * * *$ & $0.089 * * *$ & $0.223^{* * *}$ & $0.157 * * *$ & 0.044 & 0.071 \\
\hline & $(0.026)$ & $(0.031)$ & $(0.025)$ & $(0.031)$ & $(0.046)$ & $(0.050)$ \\
\hline \multirow[t]{2}{*}{ Linguistic similarity } & $0.751 * * *$ & $0.733 * * *$ & $0.727 * * *$ & $0.708 * * *$ & $0.834 * * *$ & $0.760 * * *$ \\
\hline & $(0.026)$ & $(0.032)$ & $(0.027)$ & $(0.032)$ & $(0.035)$ & $(0.040)$ \\
\hline \multirow[t]{2}{*}{ Colonial link } & $0.667 * * *$ & $0.733^{* * *}$ & $0.525 * * *$ & $0.584^{* * *}$ & $0.726 * * *$ & $0.698 * * *$ \\
\hline & $(0.042)$ & $(0.053)$ & $(0.042)$ & $(0.054)$ & $(0.061)$ & $(0.076)$ \\
\hline \multirow[t]{2}{*}{ Common colonizer } & $0.742 * * *$ & $0.737 * * *$ & $0.515^{* * *}$ & $0.579 * * *$ & $0.580 * * *$ & $0.596 * * *$ \\
\hline & $(0.043)$ & $(0.046)$ & $(0.045)$ & $(0.047)$ & $(0.047)$ & $(0.048)$ \\
\hline \multirow[t]{2}{*}{ Same country } & $0.786 * * *$ & $0.932 * * *$ & $1.031 * * *$ & $1.227 * * *$ & $0.713^{* * *}$ & $1.078 * * *$ \\
\hline & $(0.099)$ & $(0.108)$ & $(0.098)$ & $(0.107)$ & $(0.120)$ & $(0.127)$ \\
\hline \multirow[t]{2}{*}{ Both in GATT/WTO } & -0.023 & -0.022 & 0.055 & 0.137 & $0.125^{*}$ & 0.154 \\
\hline & $(0.043)$ & $(0.066)$ & $(0.072)$ & $(0.105)$ & $(0.074)$ & $(0.105)$ \\
\hline \multirow[t]{2}{*}{ One in GATT/WTO } & $-0.123^{*}$ & $-0.449 * * *$ & 0.036 & -0.151 & $-0.181^{*}$ & $-0.270^{*}$ \\
\hline & $(0.075)$ & $(0.125)$ & $(0.093)$ & $(0.148)$ & $(0.104)$ & $(0.158)$ \\
\hline \multirow[t]{2}{*}{ Polity } & $-0.396 * * *$ & $-0.306 * * *$ & 0.028 & $0.111^{* *}$ & 0.030 & $0.094 * *$ \\
\hline & $(0.018)$ & $(0.022)$ & $(0.034)$ & $(0.046)$ & $(0.034)$ & $(0.046)$ \\
\hline \multirow[t]{2}{*}{ Political constraints } & $0.508 * * *$ & $0.363^{* * *} *$ & $0.232 * * *$ & -0.027 & $0.252 * * *$ & -0.037 \\
\hline & $(0.037)$ & $(0.040)$ & $(0.052)$ & $(0.059)$ & $(0.053)$ & $(0.059)$ \\
\hline \multirow[t]{2}{*}{ Importer price } & $-0.301 * * *$ & $-0.261^{* * *}$ & $-0.134 * *$ & -0.008 & -0.093 & -0.002 \\
\hline & $(0.020)$ & $(0.026)$ & $(0.058)$ & $(0.071)$ & $(0.059)$ & $(0.071)$ \\
\hline \multirow[t]{2}{*}{ Constant } & $4.430 * * *$ & $5.871 * * *$ & $1.475 * * *$ & 0.848 & 0.866 & 0.928 \\
\hline & $(0.265)$ & $(0.341)$ & $(0.348)$ & $(0.822)$ & $(0.640)$ & $(0.821)$ \\
\hline Observations & 100614 & 74132 & 100614 & 74132 & 153464 & 109310 \\
\hline R-squared & 0.51 & 0.51 & 0.54 & 0.54 & 0.54 & 0.54 \\
\hline Time Dummies & Yes & Yes & Yes & Yes & Yes & Yes \\
\hline Exporter + Importer dummies & No & No & Yes & Yes & Yes & Yes \\
\hline Joint significance test & $3229.65^{* * *}$ & $2792.15 * * *$ & $1041.67 * * *$ & $762.46 * * *$ & $79508.92 * * *$ & $55277.82 * * *$ \\
\hline
\end{tabular}

All variables are calculated relative to the USA as base. Columns 3-6 include country fixed effects.

Standard errors in parentheses; * significant at 10\%; ** significant at 5\%; *** significant at $1 \%$ 
Table 8: Effect of Corruption and Import Duty on Bilateral Exports

\begin{tabular}{|c|c|c|c|}
\hline & (1) & $(2)$ & (3) \\
\hline & OLS & Heckman & OLS \\
\hline \multirow{2}{*}{ Corruption (importer) } & $-0.370 * * *$ & $-0.372 * * *$ & $-0.323 * * *$ \\
\hline & $(0.128)$ & $(0.105)$ & $(0.069)$ \\
\hline \multirow[t]{2}{*}{ Tariffs } & $-1.392 * * *$ & $-1.381^{* * *}$ & $-1.084^{* * *}$ \\
\hline & $(0.432)$ & $(0.344)$ & $(0.227)$ \\
\hline \multirow[t]{2}{*}{ Tariffs*Corruption (importer) } & $0.408 * * *$ & $0.410^{* * *}$ & $0.330 * * *$ \\
\hline & $(0.132)$ & $(0.107)$ & $(0.071)$ \\
\hline \multirow{2}{*}{ Tariff*Corruption square } & $-0.010 *$ & $-0.010 * *$ & $-0.005^{*}$ \\
\hline & $(0.005)$ & $(0.004)$ & $(0.003)$ \\
\hline \multirow[t]{2}{*}{ Corruption (exporter) } & -0.001 & 0.001 & $-0.016^{* *}$ \\
\hline & $(0.012)$ & $(0.010)$ & $(0.006)$ \\
\hline \multirow[t]{2}{*}{ log GDP (exporter) } & $0.808 * * *$ & $0.807 * * *$ & $0.728 * * *$ \\
\hline & $(0.059)$ & $(0.038)$ & $(0.025)$ \\
\hline \multirow[t]{2}{*}{ log GDP (importer) } & $0.754 * * *$ & $0.745^{* * *}$ & $0.776 * * *$ \\
\hline & $(0.053)$ & $(0.041)$ & $(0.027)$ \\
\hline \multirow[t]{2}{*}{ Log distance } & $-1.157 * * *$ & $-1.147^{* * *}$ & \\
\hline & $(0.037)$ & $(0.010)$ & \\
\hline \multirow[t]{2}{*}{ Contiguous } & 0.086 & $0.101^{* *}$ & \\
\hline & $(0.172)$ & $(0.039)$ & \\
\hline \multirow[t]{2}{*}{ Common official language } & $0.262 * * *$ & $0.239 * * *$ & \\
\hline & $(0.098)$ & $(0.031)$ & \\
\hline \multirow[t]{2}{*}{ Linguistic similarity } & $0.223^{* *}$ & $0.219 * * *$ & \\
\hline & $(0.097)$ & $(0.030)$ & \\
\hline \multirow[t]{2}{*}{ Colonial link } & $1.005^{* * *}$ & $1.003^{* * *}$ & \\
\hline & $(0.137)$ & $(0.037)$ & \\
\hline \multirow[t]{2}{*}{ Common colonizer } & $0.425 * * *$ & $0.425^{* * *}$ & \\
\hline & $(0.116)$ & $(0.031)$ & \\
\hline \multirow[t]{2}{*}{ Same country } & $0.982 * * *$ & $0.942 * * *$ & \\
\hline & $(0.279)$ & $(0.056)$ & \\
\hline \multirow{2}{*}{ Both in GATT/WTO } & -0.030 & -0.030 & -0.020 \\
\hline & $(0.044)$ & $(0.026)$ & $(0.018)$ \\
\hline \multirow[t]{2}{*}{ One in GATT/WTO } & -0.202 & $-0.228 * * *$ & $0.366^{* * *}$ \\
\hline & $(0.180)$ & $(0.066)$ & $(0.058)$ \\
\hline \multirow[t]{2}{*}{ Polity (exporter) } & 0.001 & 0.001 & -0.002 \\
\hline & $(0.003)$ & $(0.002)$ & $(0.002)$ \\
\hline \multirow[t]{2}{*}{ Polity (importer) } & $0.009 * * *$ & $0.009 * * *$ & $0.008 * * *$ \\
\hline & $(0.003)$ & $(0.003)$ & $(0.002)$ \\
\hline \multirow[t]{2}{*}{ Political constraints (exporter) } & $0.147^{* *}$ & $0.144^{* * *}$ & $0.252 * * *$ \\
\hline & $(0.061)$ & $(0.048)$ & $(0.032)$ \\
\hline \multirow[t]{2}{*}{ Political constraints (importer) } & $0.240 * * *$ & $0.231^{* * *}$ & $0.298 * * *$ \\
\hline & $(0.063)$ & $(0.050)$ & $(0.032)$ \\
\hline Exporter price & $-0.330 * * *$ & $-0.316^{* * *}$ & $-0.376^{* * *}$ \\
\hline & $(0.058)$ & $(0.039)$ & $(0.026)$ \\
\hline Importer price & $-0.193 * * *$ & $-0.187 * * *$ & $-0.234^{* * *}$ \\
\hline & $(0.052)$ & $(0.043)$ & $(0.028)$ \\
\hline Constant & $-20.779 * * *$ & $-21.314 * * *$ & $-31.483^{* * *}$ \\
\hline & $(2.194)$ & $(1.318)$ & $(0.842)$ \\
\hline Observations & 70367 & 94871 & 70412 \\
\hline R-squared & 0.78 & 0.79 & 0.21 \\
\hline Time Dummies & Yes & Yes & Yes \\
\hline Exporter + Importer dummies & Yes & Yes & No \\
\hline Country pair dummies & No & No & Yes \\
\hline Joint significance test & $608.79 * * *$ & $578.46 * * *$ & $262.29 * * *$ \\
\hline
\end{tabular}

Standard errors adjusted for clustering on country-pairs; * significant at 10\%; ** significant at 5\%; *** significant at $1 \%$ Import duty is the tariff measure used. All columns use GDP deflators. Columns 1 and 2 include country fixed effects; column 3 includes country-pair fixed effects. 
Table 9: Decade Averages (1980-85; 85-90; 90-95; 95-00)

\begin{tabular}{lll}
\hline & $(1)$ & $(2)$ \\
\hline \multirow{2}{*}{ Corruption (importer) } & $-1.451^{* * *}$ & -0.223 \\
Tariffs & $(0.239)$ & $(0.200)$ \\
& $-6.926^{* * *}$ & -0.813 \\
Tariffs*Corruption (importer) & $(0.756)$ & $(0.637)$ \\
& $1.432^{* * *}$ & 0.137 \\
Tariff*Corruption square & $(0.242)$ & $(0.203)$ \\
& $-0.040^{* * *}$ & 0.007 \\
Corruption (exporter) & $(0.008)$ & $(0.007)$ \\
& $-0.131^{* * *}$ & 0.007 \\
Constant & $(0.017)$ & $(0.017)$ \\
& $-27.386^{* * *}$ & $-21.440^{* * *}$ \\
Observations & $(1.032)$ & $(2.859)$ \\
R-squared & 19579 & 19579 \\
Time Dummies & 0.75 & 0.81 \\
Exporter + Importer Dummies & Yes & Yes \\
\hline Joint significance test & No & Yes \\
\hline Regressions include all variable from the model 1 in table 1 (not reported). Import duty is the tariff measure used.
\end{tabular}

Regressions include all variable from the model 1 in table 1 (not reported). Import duty is the tariff measure used.

Standard errors adjusted for clustering on country-pairs;* significant at $10 \%$; ** significant at $5 \%$; *** significant at $1 \%$

F Stat $=2.62 ;$ p-value 0.03 
Fig. 1 - The optimal zeal and evasion

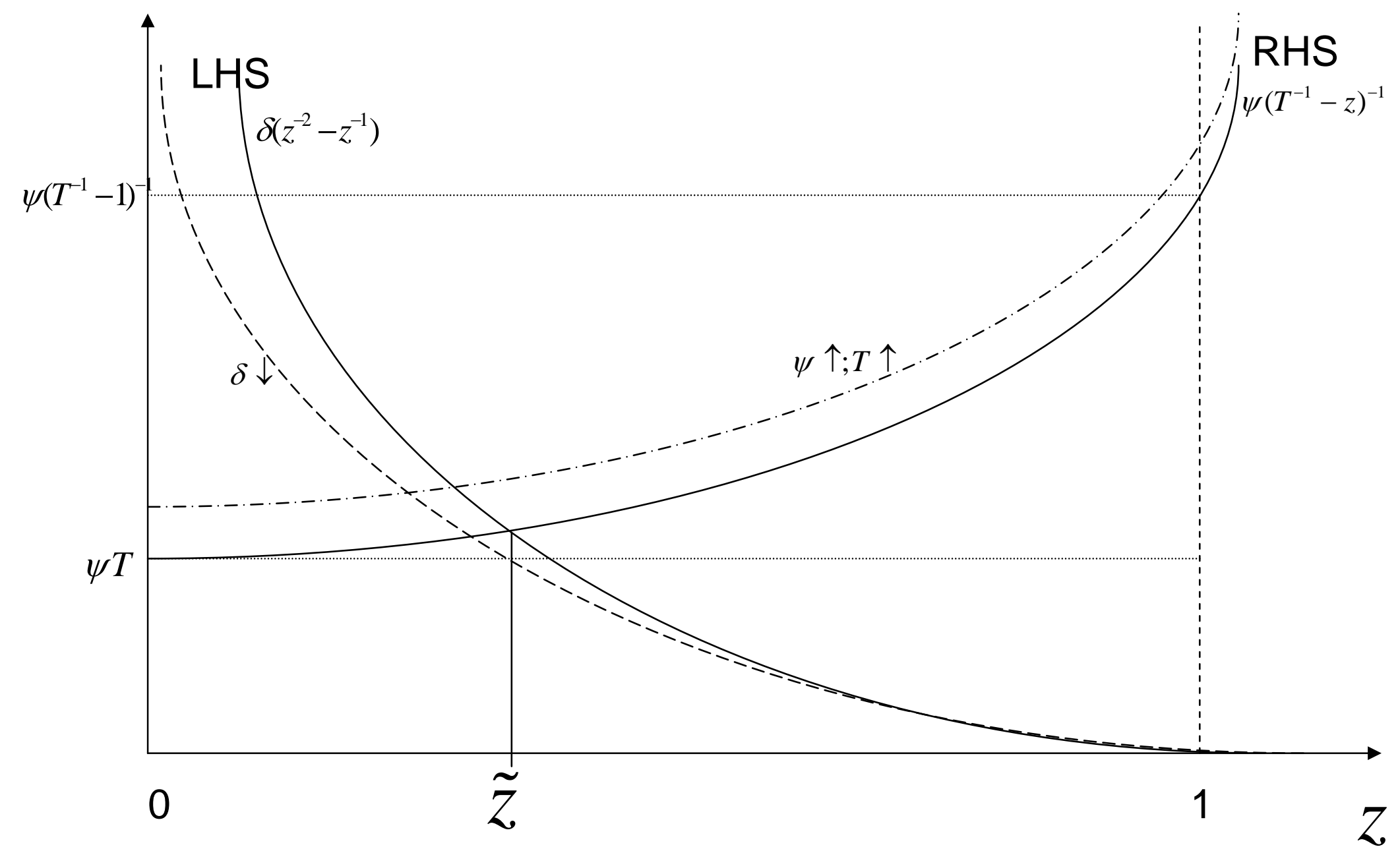


Fig 2. The Corruption Tax and its components

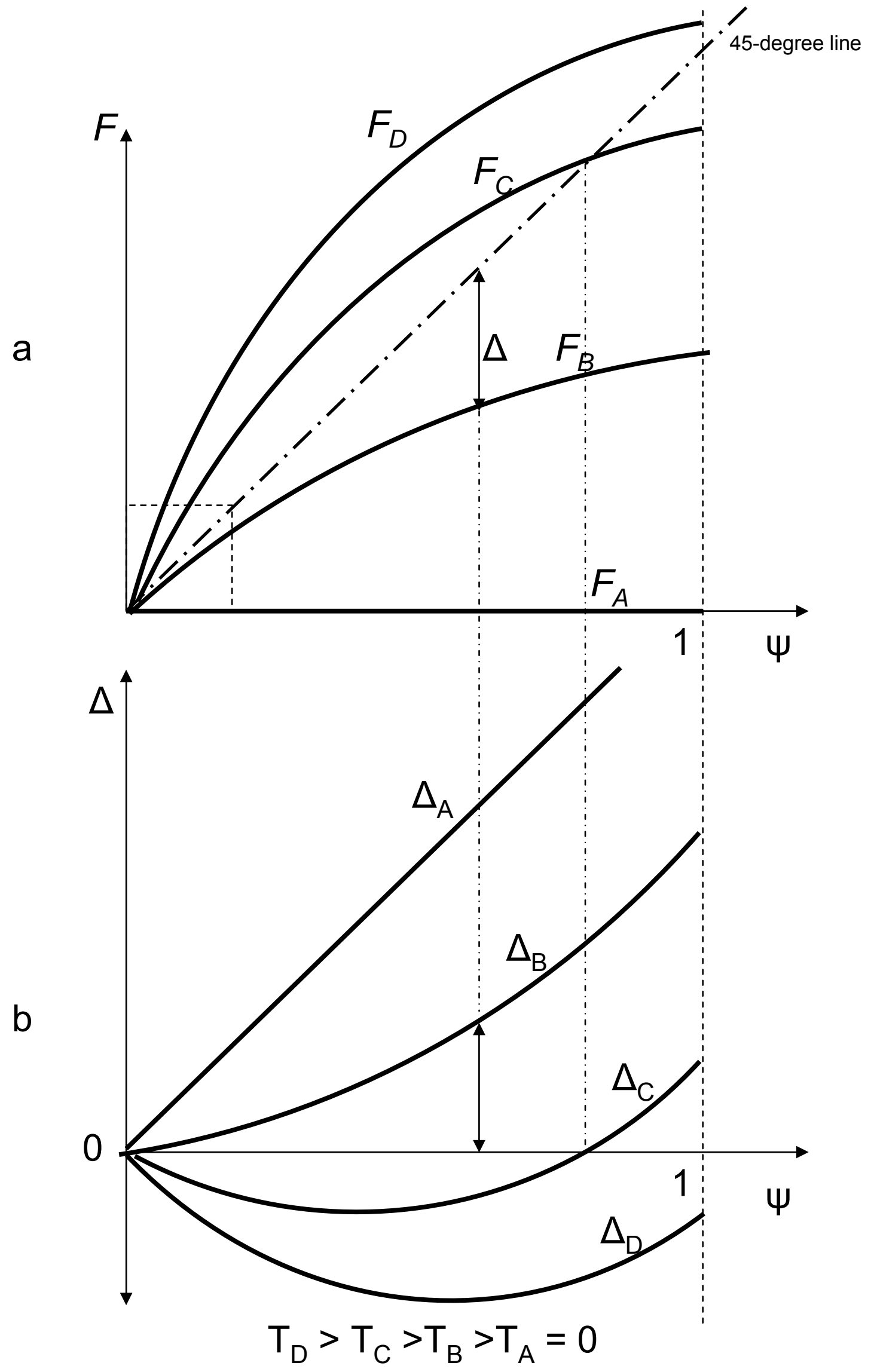

